\title{
Production of organic and inorganic carbon within a large-scale coccolithophore bloom in the northeast Atlantic Ocean
}

\author{
Emilio Fernández ${ }^{1,2}$, Philip Boyd ${ }^{3}$, Patrick M. Holligann ${ }^{1}$, Derek S. Harbour ${ }^{1}$ \\ ${ }^{1}$ Plymouth Marine Laboratory, Prospect Place, West Hoe, Plymouth PL1 3DH, United Kingdom \\ ${ }^{2}$ Departamento de Biología de Organismos y Sistemas, Universidad de Oviedo, E-33005 Oviedo, Spain \\ ${ }^{3}$ Queen's University of Belfast, School of Biology and Biochemistry, Marine Biology Station, The Strand, Portaferry, \\ County Down, Northern Ireland BT22 1PF, United Kingdom
}

\begin{abstract}
An extensive bloom $\left(250000 \mathrm{~km}^{2}\right)$ of the coccolithophore Emiliania huxleyi developed in the northeast Atlantic in June 1991. At the time of the observations in late June, the centre of the bloom was characterised by low concentrations of chlorophyll a $\left(<1 \mathrm{mg} \mathrm{m}^{-3}\right)$ and particulate organic carbon $\left(<200 \mathrm{mg} \mathrm{m}^{-3}\right.$ ) and high particulate inorganic carbon (PIC) (>300 $\mathrm{mg} \mathrm{m}^{-3}$ ) values. Photosynthesisirradiance experiments carried out along the cruise track showed the existence of a negative exponential relationship between assimilation number $\left(P_{\max }^{\mathrm{B}}\right)$ and PIC. Significant rates of inorganic carbon incorporation were only measurable in surface waters at the periphery of the bloom and in subsurface waters north of $61^{\circ} \mathrm{N}$. Calcification rates of up to $1.5 \mathrm{mg} \mathrm{C} \mathrm{m}^{-3} \mathrm{~h}^{-1}$ were measured. In general, a direct relationship was found between calcification rates and $P_{\max }^{\mathrm{B}}$ or chlorophyll $a$-normalized photosynthesis. Calcification-irradiance curves revealed that significant amounts of carbon were incorporated into coccoliths in darkness and also that, on some occasions, calcification in subsurface populations saturated at higher irradiances than in surface ones. An empirical model based on the biomass of E. huxleyi and Coccolithus pelagicus and the beam attenuation coefficient accounted for a large proportion $(>70 \%)$ of the variability in surface rates of calcification. Estimates of calcification rates derived from the model are consistent with previously reported data and compatible with the measured stocks of PIC and with the duration of the bloom as revealed by satellite imagery.
\end{abstract}

\section{INTRODUCTION}

Coccolithophores are a group of phytoplankton species of the class Prymnesiophyceae that is widely distributed in the oceans (Okada \& McIntyre 1977). Emiliania huxleyi (Lohm.) Hay et Mohler is the most abundant species within this group, and is possibly the major producer of calcite in the biosphere (Westbroek et al. 1985). The ability of this species to form blooms in coastal waters has been known since early this century (Gran 1912). However, their large-scale occurrence was only shown by ocean colour imagery (Holligan et al. 1983, Groom \& Holligan 1987). Studies on the global distribution of coccolithophore blooms (C. Brown \& J. Yoder unpubl.) revealed the North Atlantic as the oceanic region where they are most frequent and extensive. In this connection, patches of high reflectance surface waters have been reported for the North Sea (Holligan et al. 1989), western English Channel (Holligan et al. 1983), Gulf of Maine (Balch et al. 1991) oceanic regions of the North Atlantic Ocean (Aiken \& Bellan 1990, Brown \& Yoder 1993) and in the Norwegian Sea (Trees et al. 1992).

The importance of coccolithophores in the biogeochemical cycling of carbon is based not only on their capacity for organic matter production by photosynthesis, but on their unique ability amongst the phytoplankton to synthesize external plates of calcite, called coccoliths, which represent a large proportion of the flux of particulate carbon to the deep ocean. Thus, coccolithophores are known to contribute significantly to the fine fraction of oceanic sediments in those areas where the sea floor lies above the lysocline (Bramlette 1958). 
Although over geological time scales the production in the photic layer of calcium carbonate by coccolithophores represents a net sink of carbon into the sediments (Whitfield \& Watson 1983), the immediate effect of calcification is a relative increase of $\mathrm{pCO}_{2}$, in part controlled by the buffering capacity of seawater in surface waters due to the assimilation of bicarbonate according to the equation:

$$
2 \mathrm{HCO}_{3}^{-}+\mathrm{Ca}^{2+}=\mathrm{CaCO}_{3}+\mathrm{CO}_{2}+\mathrm{H}_{2} \mathrm{O}
$$

and a parallel drop in alkalinity which, in turn, shifts the dissolved inorganic carbon (DIC) equilibrium in the direction of $\mathrm{CO}_{2}$ (Robertson et al. 1993). In addition, increases in water temperature within Emiliania huxleyi blooms as a result of light scattering in the water, primarily due to detached coccoliths (Holligan et al. 1993), contribute to increase the partial pressure of $\mathrm{CO}_{2}$ in the water slowing the flux of carbon dioxide from the atmosphere. This ability of coccolithophores to alter the DIC system by means of the interacting effects of photosynthesis, calcification and light scattering, has been found to exert a significant effect on the fluxes of $\mathrm{CO}_{2}$ between the ocean and the atmosphere (Robertson et al. 1993). It has also been hypothesised that, as a consequence of shifts in phytoplankton composition over geological time scales, changes in the ratio of organic $\mathrm{C}$ to $\mathrm{CaCO}_{3}$ burial contribute to variations in atmospheric $\mathrm{CO}_{2}$ (Volk 1989), and through effects on sea water alkalinity represent an ecological mechanism which partially accounts for glacial-interglacial variations in atmospheric $\mathrm{pCO}_{2}$ (Berger \& Keir 1984).

A number of studies using coccolithophore cultures have focussed on the process of coccolith formation (Sikes et al. 1980, Sikes \& Wilbur 1982, De Jong et al. 1983, Nimer \& Merret 1992, Sikes \& Fabry 1993) and on its regulation by environmental factors such as light intensity (Paasche 1964, Linschooten et al. 1991, Balch et al. 1992), and spectral quality (Paasche 1966b), photoperiod (Paasche 1968), temperature (Watabe \& Wilbur 1966, Paasche 1968) and nitrogen availability (Baumann et al. 1978, Balch et al. 1992). These studies have shown that the interaction between photosynthesis and calcification and the effect of environmental variables on coccolith formation are complex (see review in Klaveness \& Paasche 1979). Little is known, however, about the environmental variables controlling the onset and decline of coccolithophore blooms, and on the patterns of organic and inorganic production during such events. In this regard, Balch et al. (1992) reported some of the first field measurements of phosynthesis and calcification rates by coccolithophores for a coastal Emiliania huxleyi bloom in the Gulf of Maine.
The main aims of the present study were (1) to measure photosynthesis and calcification rates and the resulting standing stocks within a large scale Emiliania huxleyi bloom sampled in June 1991 in the NE Atlantic to the south of Iceland, (2) to describe their variability at different spatial scales and (3) to determine the variations in these processes associated with the different phases of development of the bloom. Companion papers have assessed the biogeochemical significance of the bloom (Holligan et al. 1993) and more specifically its impact on the exchange of carbon dioxide between the atmosphere and surface waters (Robertson et al. 1993).

\section{METHODS}

The present survey was carried out on board RRS 'Charies Darwin' from 13 June to 3 July 1991. The cruise track was determined using real-time satellite imagery from the Advanced Very High Resolution Radiometer (AVHRR) sensor aboard the NOAA-9 satellite. Image processing was performed as in Groom \& Holligan (1987). During the first part of the cruise observations were made along the $20^{\circ} \mathrm{W}$ meridian from $56^{\circ} \mathrm{N}$ to $63^{\circ} \mathrm{N}$. Several underway transects and 3 main working stations at (A) $60^{\circ} 00^{\prime} \mathrm{N}, 20^{\circ} 00^{\prime} \mathrm{W}$, (B) $61^{\circ} 05^{\prime} \mathrm{N}, 22^{\circ} 45^{\prime} \mathrm{W}$ and (C) $61^{\circ} 12^{\prime} \mathrm{N}, 15^{\circ} 09^{\prime} \mathrm{W}$, were sampled (Fig. 1).

Hydrographic and standing stock variables. Surface water was collected from a depth of 2 to $3 \mathrm{~m}$ through

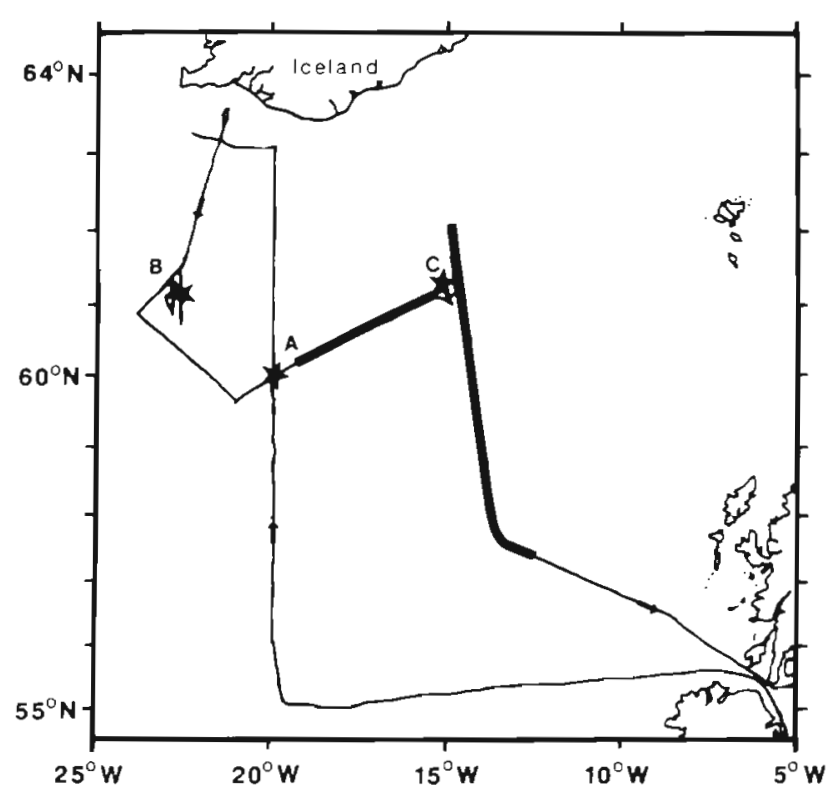

Fig. 1. Cruise track of RRS 'Charles Darwin' 13 June to 3 July 1991 showing the position of the 3 in situ productivity areas (A, $\mathrm{B}$ and $\mathrm{C})$. Bold lines indicate the 2 transects described in the text 
the ship's non-toxic seawater supply for continuous measurements of temperature, salinity, beam attenuation and dissolved nitrate as described in Robertson et al. (1993) and Holligan et al. (1993). Discrete surface samples were taken every hour for phytoplankton cell counts and the determination of chlorophyll a (chl a), total particulate carbon and calcium concentrations. Identification and enumeration of phytoplankton cells were performed by examining samples preserved in both Lugol's iodine and buffered formalin with an inverted microscope. Coccolithophores were counted in the formalin-preserved samples. Cell counts were converted to carbon biomass as described in Holligan et al. (1984). Cell to carbon conversion factors for Emiliania huxleyi and Coccolithus pelagicus were $13 \mathrm{pg} \mathrm{C}$ cell $^{-1}$ and $233 \mathrm{pg} \mathrm{C}$ cell $^{-1}$ respectively. Chl a was measured by fluorometric assay after filtration on $\mathrm{GF} / \mathrm{F}$ glass fibre filters and extraction for $24 \mathrm{~h}$ at $4{ }^{\circ} \mathrm{C}$ with $90 \%$ acetone.

Total particulate carbon (TPC) and particulate inorganic carbon (PIC) were measured from material retained on Whatman $\mathrm{GF} / \mathrm{F}$ filters after filtration of $0.5 \mathrm{l}$ of seawater and subsequently frozen at $-20^{\circ} \mathrm{C}$. TPC was analysed with a Carlo-Erba 1500 series $2 \mathrm{CHN}$ analyser without treatment to remove carbonates. PIC was estimated from the measured calcium content, assuming that all of the particulate calcium was present as calcium carbonate. Calcium concentration was determined by flame atomic absorption spectrometry using an air-acetylene flame at $422.7 \mathrm{~nm}$ wavelength. Samples were made up with $1 \%$ lanthanum chloride as a releasing agent to remove phosphorus supression of ionization. Particulate organic carbon (POC) was calculated by subtracting PIC from TPC.

The same set of variables was also measured at the CTD and productivity stations using water samples collected with a rosette of oceanographic Niskin bottles. Vertical profiles of temperature and salinity were obtained with a Neil Brown CTD attached to the rosette.

Photosynthesis and calcification. Photosynthesis and calcification rates were measured by the ${ }^{14} \mathrm{C}$ method (Paasche 1963 Balch et al. 1992). All water samples were manipulated with clean laboratory techniques. Three different sampling and/or experimental approaches were conducted for the study of photosynthesis and calcification rates in this survey: (a) underway surface measurements, (b) in situ measurements and (c) photosynthesis-irradiance (P-I) and calcification-irradiance (C-I) experiments.

Water samples were transferred to $60 \mathrm{ml}$ polycarbonate bottles previously treated as described by Joint et al. (1993). $370 \mathrm{kBq}(10 \mathrm{mCi}) \mathrm{NaH}^{14} \mathrm{CO}_{3}$ was added to each bottle and then incubated in situ, on deck or under artificial light. Three time-zero samples were filtered onto $0.2 \mu \mathrm{m}$ polycarbonate filters (in situ incubations) or $0.2 \mu \mathrm{m}$ Whatman membrane filters (other experiments) immediately after inoculation with $\mathrm{NaH}^{14} \mathrm{CO}_{3}$. At the same time, the specific activity of each $\mathrm{NaH}^{14} \mathrm{CO}_{3}$ stock solution was also determined. After the incubation period, samples were divided into 2 fractions and each filtered through $0.2 \mu \mathrm{m}$ Whatman membrane filters under low vacuum pressure $(<100 \mathrm{~mm} \mathrm{Hg})$. One of the filters (Filter 'a') was carefully rinsed twice with filtered $(0.2 \mu \mathrm{m})$ seawater and placed into a desiccator for at least $24 \mathrm{~h}$. After this period any soluble labelled bicarbonate still adsorbed to the filter is transformed into $\mathrm{CO}_{2}$ (Joint \& Pomroy 1983). The second filter (Filter ' $b$ ') was rinsed, exposed for $5 \mathrm{~min}$ to concentrated $\mathrm{HCl}$ fumes and dried in a desiccator. All filters were counted in a LKB Wallace Packard liquid scintillation counter. Quenching was corrected using the channels ratio method. The radioactivity measured on Filter ' $b$ ' was taken to measure photosynthetic $\mathrm{C}$ incorporation as it was assumed that the fuming treatment exclusively removed calcite associated with coccoliths but did not affect the organic carbon pool. Calcification was calculated as the difference between the activity measured on Filters 'a' and ' $b$ '.

Surface water samples for photosynthesis/calcification incubations were collected every hour from the non-toxic water supply along 2 transects running from $60^{\circ} 10^{\prime} \mathrm{N}, 19^{\circ} 24^{\prime} \mathrm{W}$ to $61^{\circ} 11^{\prime} \mathrm{N}, 15^{\circ} 14^{\prime} \mathrm{W}$ and $62^{\circ} 00^{\prime} \mathrm{N}, 15^{\circ} 10^{\prime} \mathrm{W}$ to $57^{\circ} 26^{\prime} \mathrm{N}, 13^{\circ} 05^{\prime} \mathrm{W}$ respectively (see Fig. 1). Comparative experiments carried out during the cruise revealed that the differences in photosynthesis and calcification rates between water samples taken simultaneously from the non-toxic water supply and directly from the sea were not significant ( $t$-test; $p<0.05)$. Samples were placed in an 'on deck' incubator under natural light conditions. Sea surface water was circulated in the incubator to maintain the samples at ambient temperature. Samples taken during the night were stored in 11 polycarbonate bottles at ambient surface temperature until next morning, when they were transferred to the $60 \mathrm{ml}$ incubation bottles and then inoculated with $\mathrm{NaH}^{14} \mathrm{CO}_{3}$. Incubations were carried out between 10:00 and 18:00 h, so that irradiance levels reaching the bottles were always saturating, at least for photosynthesis. Incubations lasted ca $4 \mathrm{~h}$.

Vertical profiles for the determination of organic and inorganic carbon production were conducted in situ at 5 stations. Water samples were taken before dawn with Go-Flo bottles on a Kevlar line. Three $60 \mathrm{ml}$ polycarbonate bottles were filled from each depth, inoculated with $\mathrm{NaH}^{14} \mathrm{CO}_{3}$ and suspended at dawn for $24 \mathrm{~h}$ from a free-floating incubation rig at the depths where the samples were taken. Further filtration procedures and manipulation of the filters were done as described above. 

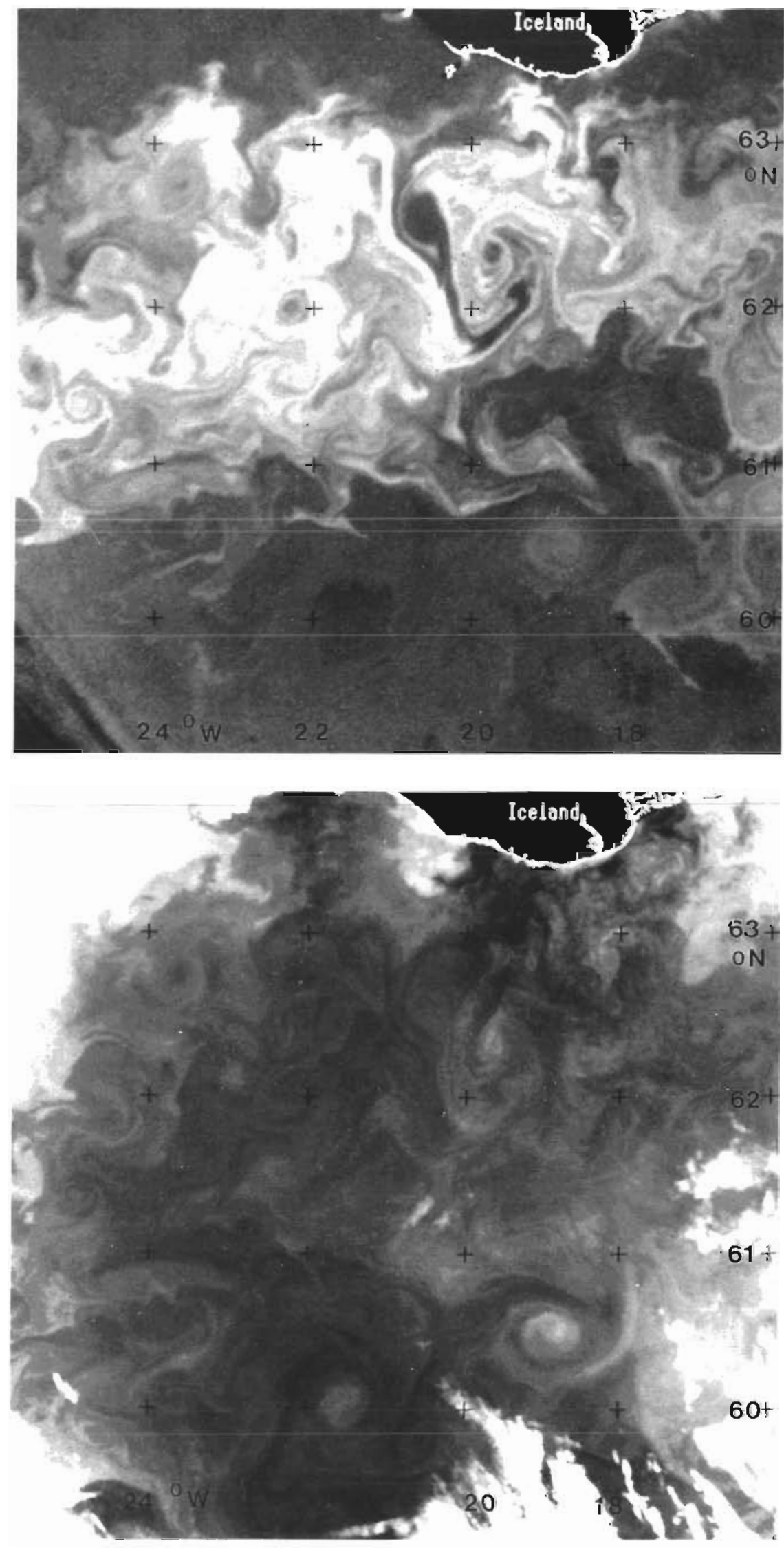

The relationship between irradiance and organic or inorganic carbon incorporation by phytoplankton was examined in a number of experiments undertaken with water collected either from the non-toxic water supply or the rosette sampler. Samples were transferred to the incubation bottles, inoculated with 370 to $555 \mathrm{kBq}(10$ to $15 \mathrm{mCi}$ ) $\mathrm{NaH}^{14} \mathrm{CO}_{3}$ and then placed in an incubator. On-deck incubators simulated a range of irradiances $(58,36$, $28,19,10$ and $5 \%$ of surface values) by means of neutral-density plastic screens. P-I and C-I experiments were done in the ship's radiocarbon laboratory in an incubator where the samples were cooled with circulating water at ambient surface temperature and a light gradient (24 light levels from 4 to $1200 \mu \mathrm{E}$ $\mathrm{m}^{-2} \mathrm{~s}^{-1}$ ) was obtained using a $500 \mathrm{~W}$ tungsten-halogen lamp as described in Joint \& Pomroy (1986).

Photosynthetic rates normalised to chl a concentration were fitted to the hyperbolic tangent (Jassby \& Platt 1976) or the continuous exponential functions (Platt et al. 1980) depending on the evidence of photoinhibition. Calcification rates were normalised to coccolithophore carbon biomass as estimated from cell counts (see above). For this, only the biomass of Emiliania huxleyi and Coccolithus pelagicus was considered as calcification rates in Holococcolithophorids are low (Van der Wal et al. 1983), on the basis of the small amounts of inorganic carbon present in their calcified structures in relation to the organic matrix

All statistical analysis were performed using various SAS procedures (SAS Institute 1985).

Fig. 2. Advanced Very High Resolution Radiometer (AVHRR) imagery of the Emiliania huxleyi bloom on 17 June 1991. Upper panel: visible band (channel. 1) surface reflectance image. Lighter shades indicates higher reflectance. Lower panel: infrared (channel 4) image. Cold water is indicated by light shades 


\section{RESULTS}

\section{Bloom development and standing stocks of particulate carbon}

An extensive oceanic area characterized by high reflectance on AVHRR visible-band images extended from 60 to $64^{\circ} \mathrm{N}$ and 13 to $28^{\circ} \mathrm{W}$ (Fig. 2). The high reflectance signal was shown to be caused by a large scale bloom of the coccolithophore Emiliania huxleyi (Fig. 3) which developed between 5 and 10 June and lasted until early July (Holligan et al. 1993). The complex mesoscale eddy field structure could be visualized from both visible and infrared images for the Iceland Basin on 17 June (Fig. 2). Spatial differences in surface temperature did not exceed $1.5^{\circ} \mathrm{C}$ in the region. No consistent relationship between temperature and reflectance was apparent. The sequence of satellite pictures obtained during the cruise (Holligan et al. 1993) showed that the waters south of $61^{\circ} \mathrm{N}$ moved in a northeast direction associated with the North Atlantic drift. Surface waters from $61^{\circ} \mathrm{N}$ to the Iceland shelf flowed in the opposite direction.

The distribution of sigma-t at the surface (Fig. 4) reflects the patterns of water motion observed from space (Holligan et al. 1993). Relatively high density water $(<26.8$ sigma-t units) was observed to the west of the Hebrides shelf and south of $61^{\circ} \mathrm{N}$. This water masscorresponded to the flow of North Atlantic Central Water (NACW) northeastward. The westward flow was marked by lower sigma-t values, mainly caused by relatively low salinity which may have resulted from lateral mixing of NACW and Atlantic Subarctic Water, thus forming Modified North Atlantic Water (MNAW). It is interesting to note that the region of high reflectance was largely confined to the MNAW mass, although a close correspondence between sigma-t and reflectance could not be established due to the different time-scale involved in these measurements.

Surface distribution of chl a (Fig. 4) varied from less than $0.5 \mathrm{mg} \mathrm{m}^{-3}$ along the southern part of the track to $>2 \mathrm{mg} \mathrm{m}^{-3}$ in the waters over the Icelandic slope and in the areas both to the west (Area B) and east (Area C) of the cruise track along the $60^{\circ} \mathrm{N}$ meridian. Chl a values within the main part of the coccolithophore bloom were gener- ally below $1 \mathrm{mg} \mathrm{m}^{-3}$. The concentration of particulate organic carbon (POC) followed a similar pattern to that of chl a (Fig. 4). POC concentrations within the Emiliania huxleyi bloom were some of the lowest measured during the cruise $\left(<200 \mathrm{mg} \mathrm{C} \mathrm{m}^{-3}\right)$. Organic $\mathrm{C}$ to $\mathrm{ch}$ l a ratios were high (about 100) throughout the study area; the highest values were found in the northern part of the $15^{\circ} \mathrm{W}$ transect. The maximum concentrations of particulate inorganic carbon (PIC) exceeded $300 \mathrm{mg} \mathrm{C} \mathrm{m}^{-3}$. PIC has been observed to covary with satellite-derived reflectance (Holligan et al, 1993) and, in addition, was correlated with the total number of coccoliths $\left(\mathrm{ml}^{-1}\right)$ according to the equation

$$
\begin{gathered}
\mathrm{PIC}=0.000471( \pm 0.000017) \text { coccoliths }+40.31( \pm 20.95) \\
\mathrm{r}^{2}=0.92, \mathrm{n}=67
\end{gathered}
$$

For this regression, detached coccoliths and total number of coccospheres were used. Coccospheres were converted into coccoliths assuming an average of 20 coccoliths per cell (see Fig. 3). These relationships confirm previous findings relating enhanced water reflectance to backscattering of light by coccoliths (Holligan et al. 1983, Balch et al. 1991).

Regression equations were calculated for the relationship between TPC $\left(\mathrm{mg} \mathrm{m}^{-3}\right)$ and total particulate nitrogen (TPN) (mg $\mathrm{m}^{-3}$ ) for coccolithophore-rich (PIC $>100 \mathrm{mg} \mathrm{C} \mathrm{m}^{-3}$ ) and for non-coccolithophore $\left(\mathrm{PIC}<100 \mathrm{mg} \mathrm{C} \mathrm{m}^{-3}\right.$ ) surface waters. The equation for those samples with $\mathrm{PIC}<100 \mathrm{mg} \mathrm{C} \mathrm{m}^{-3}$ :

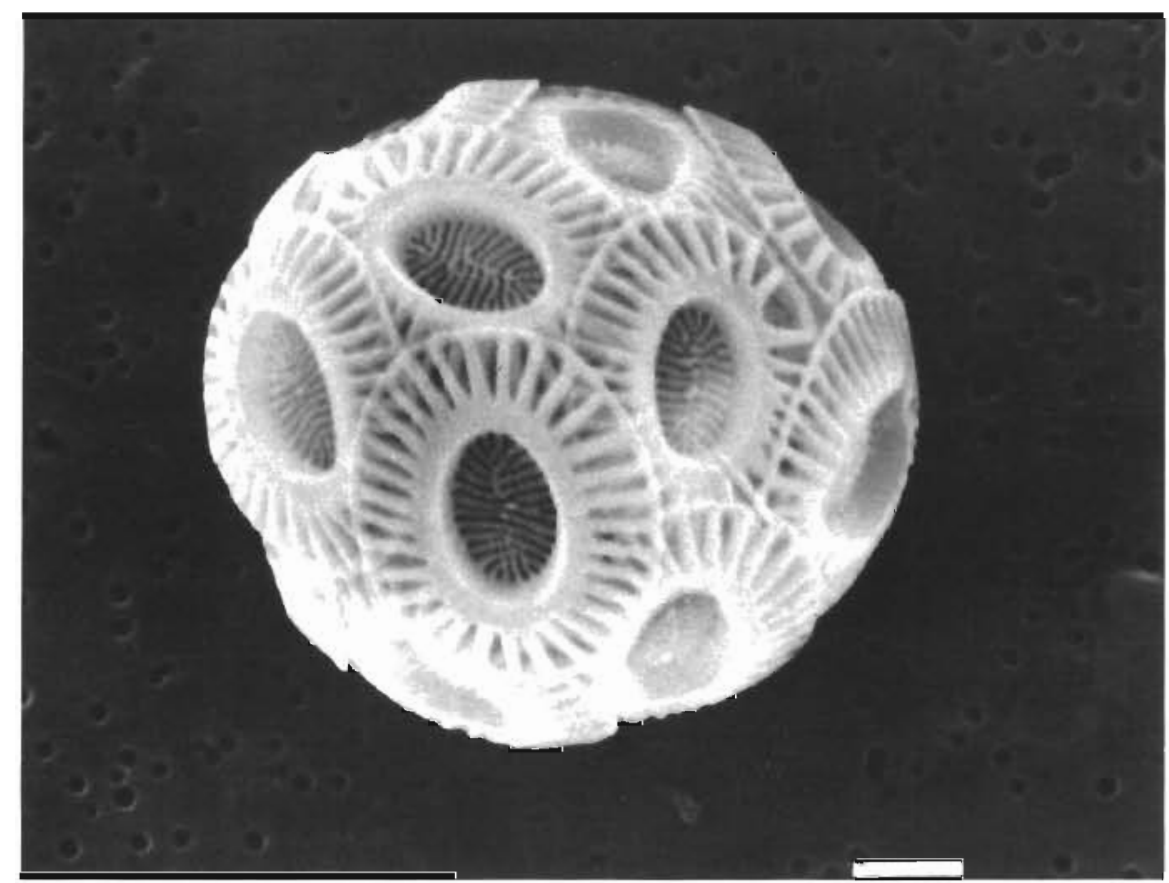

Fig. 3. Emiliania huxleye. Scanning electron micrograph of a cell-type A which dominated the $1991 \mathrm{NE}$ Atlantic bloom. Scale bar $=1 \mu \mathrm{m}$ 


$$
\begin{gathered}
\mathrm{TPC}=5.80( \pm 0.17) \mathrm{TPN}-1.15( \pm 7.99) \\
\mathrm{r}^{2}=0.91, \mathrm{n}=108
\end{gathered}
$$

yields a $C: N$ ratio for non-coccolithophore waters of 5.80 by weight ( 6.77 by atoms) which equals the Redfield ratio. The relationship obtained for coccolithophore waters:

$$
\begin{gathered}
\mathrm{TPC}=4.0( \pm 0.4) \mathrm{TPN}+181.0( \pm 23.8), \\
\mathrm{r}^{2}=0.65, \mathrm{n}=54
\end{gathered}
$$

had a highly positive intercept which indicated that the $C: N$ ratio varied with the concentration of TPN. Thus, for TPN between 20 and $100 \mathrm{mg} \mathrm{m}^{-3}$, the $\mathrm{C}: \mathrm{N}$ ratios ranged from 13.05 to 5.81 , values comparable to those found by Balch et al. (1992) in a coastal Emiliania huxleyj bloom.

Short-scale horizontal surface variability of phytoplankton biomass, photosynthesis and calcification

Short-scale spatial variability in hydrographic conditions, phytoplankton standing-stocks, coccolithophore biomass and photosynthesis and calcification rates were studied along 2 transects (Fig. 1).

The first transect was run from $60^{\circ} 10^{\prime} \mathrm{N}, 19^{\circ} 24^{\prime} \mathrm{W}$ to $61^{\circ} 12^{\prime} \mathrm{N}, 15^{\circ} 14^{\prime} \mathrm{W}$, along the southern margin of the bloom (Fig. 5). Water density (sigma-t) changed as the ship crossed different water types associated with the mesoscale eddy structure characteristic of the region (Fig. 5A). Large changes in nitrate concentration linked to small differences in sigma-t were observed at the eastern end of the transect. The beam

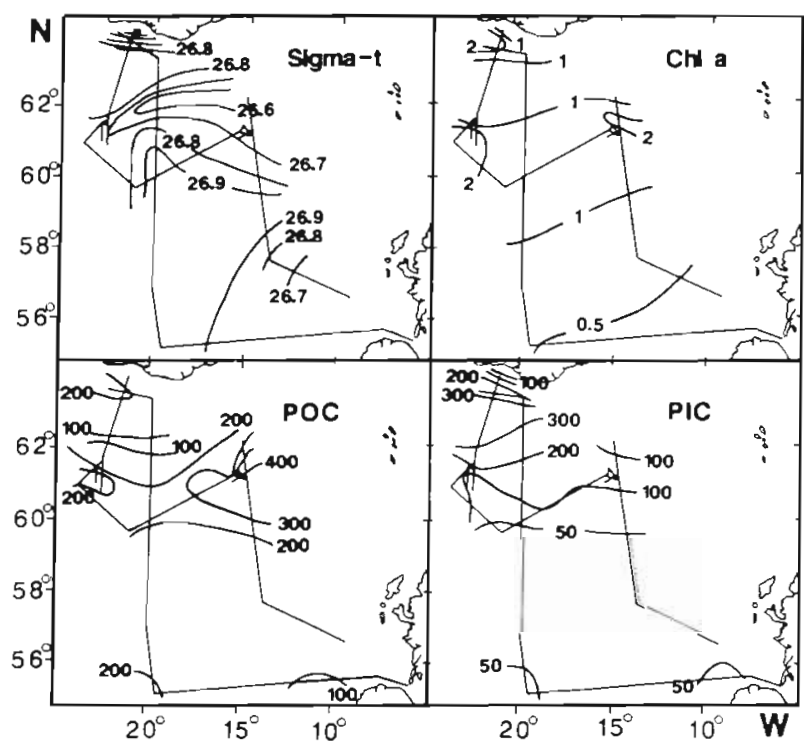

Fig. 4. Surface distribution of sigma-t, chl a $\left(\mathrm{mg} \mathrm{m}^{-3}\right)$, particulate organic carbon ( $\mathrm{POC}, \mathrm{mg} \mathrm{m}^{-3}$ ) and particulate inorganic carbon (PIC, $\mathrm{mg} \mathrm{m}^{-3}$ )

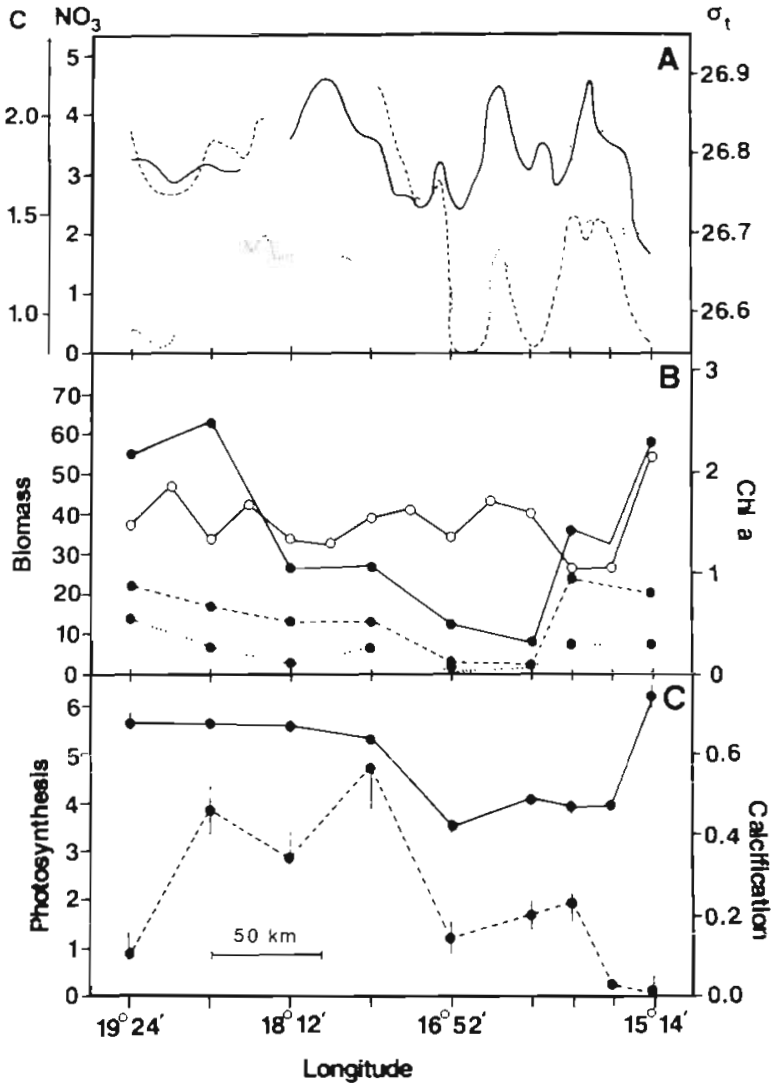

Fig. 5. Surface profiles from $60^{\circ} 10^{\prime} \mathrm{N}, 19^{\circ} 24^{\prime} \mathrm{W}$ to $61^{\circ} 12^{\prime} \mathrm{N}$, $15^{\circ} 14^{\prime} \mathrm{W}$ on 27 June 1991 for (A) sigma-t (-), $\mathrm{NO}_{3}$ $\left(-\cdots, \mu \mathrm{mol} \mathrm{I} \mathrm{I}^{-1}\right)$ and beam attenuation coefficient at $532 \mathrm{~nm}(\mathrm{c})$ $\left(\cdots . ., \mathrm{m}^{-1}\right) ;(B)$ chl a $\left(\mathrm{O}-\mathrm{O}, \mathrm{mg} \mathrm{m}^{-3}\right)$, total estimated phytoplankton biomass $\left(\bullet \longrightarrow, \mathrm{mg} \mathrm{C} \mathrm{m}^{-3}\right)$, estimated Emiliania huxleyi $\mathrm{C}$ biomass $\left(\bullet-\cdots, \mathrm{mg} \mathrm{m}^{-3}\right)$ and estimated Coccolithus pelagicus $\mathrm{C}$ biomass $\left(\bullet \cdots \bullet, \mathrm{mg} \mathrm{m}^{-3}\right)_{i}$ (C) photosynthesis $\left(\bullet \bullet, \mathrm{mg} \mathrm{C} \mathrm{m}^{-3} \mathrm{~d}^{-1}\right.$ ) and calcification $(\bullet . . . \mathrm{mg} \mathrm{C}$ $\mathrm{m}^{-3} \mathrm{~d}^{-1}$ ) rates. Error bars: $\pm 1 \mathrm{SE}$

attenuation coefficient (c) was also variable along the section, with values increasing towards the east. No apparent relationship between attenuation and sigmat or nitrate concentration was found.

Chl a concentration showed relatively small variations along the transect (Fig. 5B), most of the values ranging between 1 and $2 \mathrm{mg} \mathrm{m}^{-3}$. However, the biomass of phytoplankton was high at the $W$ and $E$ ends of the transect. Coccolithophores contributed a significant proportion of total estimated phytoplankton biomass (40 to $90 \%$ ) particularly along the eastern part of the section, where attenuation was maximum. Emiliania huxleyi was the dominant coccolithophore species, and flagellates were the largest contributor to the non-coccolithopore biomass.

Photosynthetic rates were generally high 4 to $6 \mathrm{mg} \mathrm{C}$ $\mathrm{m}^{-3} \mathrm{~h}^{-1}$ ) along the section (Fig. 5C), their distribution being related to that of chl $a$. The lowest rates were measured in areas of low nitrate concentration. Calci- 
fication was detectable (up to $0.6 \mathrm{mg} \mathrm{C} \mathrm{m}^{-3} \mathrm{~h}^{-1}$ ) between $18^{\circ} 47^{\prime} \mathrm{W}$ and $17^{\circ} 34^{\prime} \mathrm{W}$. In this region, the biomass of Emiliania huxleyi + Coccolithus pelagicus was in excess of $15 \mathrm{mg} \mathrm{C} \mathrm{m}^{-3}$. Negligible rates of inorganic carbon production $\left(<0.2 \mathrm{mg} \mathrm{C} \mathrm{m}^{-3} \mathrm{~h}^{-1}\right)$ were detected at the eastern end of the transect, even though the biomass of E. huxleyi was comparable to that found at the western end.

The second transect, running approximately along the $15^{\circ} \mathrm{W}$ parallel was sampled between $62^{\circ} \mathrm{N}$ and $53^{\circ} 30^{\prime} \mathrm{N}$ (see Fig. 1). The hydrographic and optical conditions are summarised in Fig. 6A. Three main features could be recognized: (1) a marked physicaloptical front, located between $59^{\circ}$ and $60^{\circ} \mathrm{N}$ separated low-density high-attenuation $\left(>1 \mathrm{~m}^{-1}\right)$ water to the north from water with the opposite characteristics to the south, (2) a mesoscale warm-core eddy at the northern part of the section (between $61^{\circ}$ and $61^{\circ} 30^{\prime} \mathrm{N}$ ) and (3) a patch of relatively high attenuation water at the southern end close to the Rockall Bank shelfedge.

In general, chl a distribution was correlated with total phytoplankton carbon (Fig. 6B), although the ratio between them was lower where coccolithophores prevailed. High values of these variables were associated with each of the 3 hydrographic features indicated above. Emiliania huxleyi was the dominant coccolithophore species north of $60^{\circ} \mathrm{N}$, being replaced by Coccolithus pelagicus to the south. This sequence was most marked at the front where E. huxleyi-dominated, mixed $E$. huxleyi-C. pelagicus and C. pelagicus-dominated coccolithophore assemblages alternated at ca $15 \mathrm{~km}$ intervals (Fig. 6B). Within the relatively high attenuation water over the edge of Rockall Bank C. pelagicus was dominant.

Photosynthetic rates reached values up to $7 \mathrm{mg} \mathrm{C}$ $\mathrm{m}^{-3} \mathrm{~h}^{-1}$ north of the frontal boundary (Fig. 6C). This maximum was related to an increase in phytoplankton biomass, mostly small flagellates. Relatively high levels of organic carbon production were also measured close to the Rockall Bank. Calcification was only measurable at the frontal zone between high and low attenuation waters (Fig. 6C), where typical values reached $1.5 \mathrm{mg} \mathrm{C} \mathrm{m}{ }^{-3} \mathrm{~h}^{-1}$ within a mixed Emiliania huxleyi-Coccolithus pelagicus population. The highest contribution of surface calcification to total carbon incorporation was $26 \%$

\section{Vertical variability of phytoplankton biomass, photosynthesis and calcification}

Vertical profiles of phytoplankton biomass, temperature, total particulate inorganic and organic carbon and in situ daily rates of photosynthesis and calcifica-

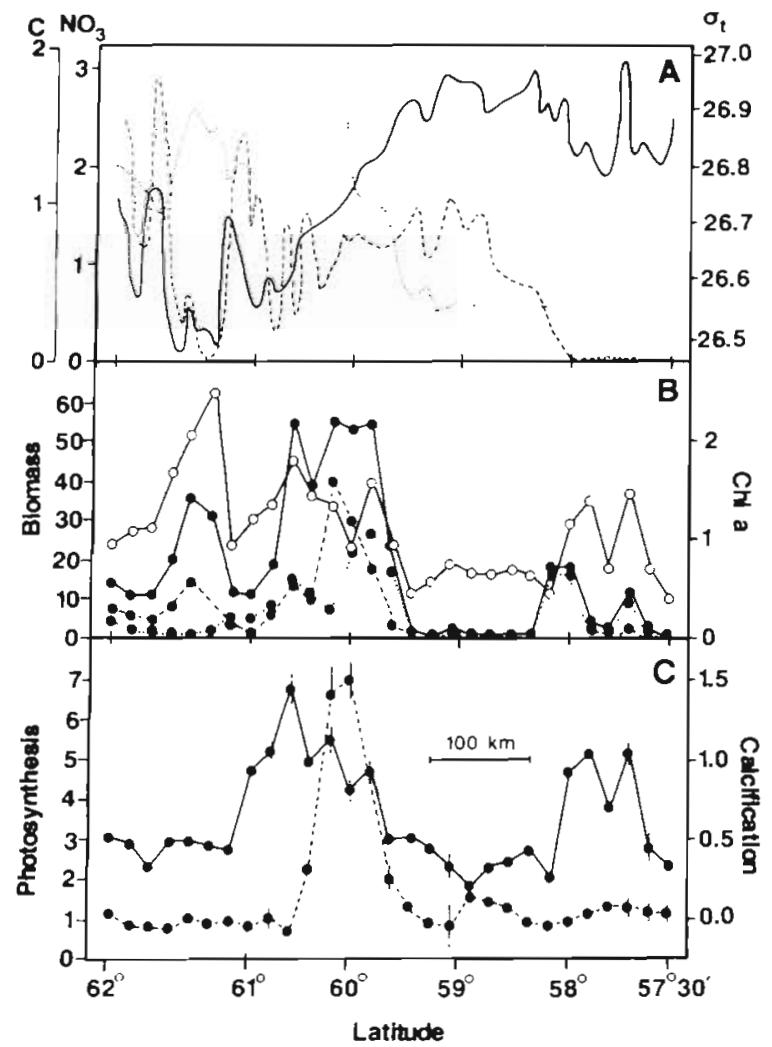

Fig. 6. Surface profiles from $15^{\circ} \mathrm{W}$ meridian between $62^{\circ}$ and $57^{\circ} 30^{\prime} \mathrm{N}$ on 30 June-1 July 1991 for (A) sigma-t (-), $\mathrm{NO}_{3}$ $\left(---, \mu \mathrm{mol} \mathrm{l}^{-1}\right)$ and beam attenuation coefficient at $532 \mathrm{~nm}(\mathrm{c})$ $\left(\ldots . ., \mathrm{m}^{-1}\right) ;(\mathrm{B}) \mathrm{chl}$ a $\left(\mathrm{O}-\mathrm{O}, \mathrm{mg} \mathrm{m}^{-3}\right)$, total estimated phytoplankton $\mathrm{C}$ biomass $\left(\bullet-\mathrm{mg} \mathrm{m}^{-3}\right)$, estimated Emiliania huxleyi $\mathrm{C}$ biomass $\left(\bullet-.-\bullet, \mathrm{mg} \mathrm{m}^{-3}\right)$ and estimated Coccolithus

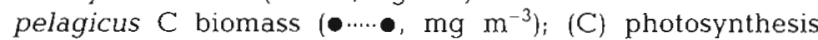
$\left(\bullet, \mathrm{mg} \mathrm{C} \mathrm{m} \mathrm{m}^{-3} \mathrm{~h}^{-1}\right.$ ) and calcification $(\bullet-\cdots, \mathrm{mg} \mathrm{C}$ $\mathrm{m}^{-3} \mathrm{~h}^{-1}$ ) rates. Error bars: $\pm 1 \mathrm{SE}$

tion are shown for 3 areas: $\mathrm{A}\left(60^{\circ} \mathrm{N}, 20^{\circ} \mathrm{W}\right), \mathrm{B}\left(61^{\circ} \mathrm{N}\right.$, $\left.23^{\circ} \mathrm{W}\right)$ and $\mathrm{C}\left(61^{\circ} \mathrm{N}, 15^{\circ} \mathrm{W}\right)$ (Figs. $7 \& 8$ ).

At Area $\mathrm{A}$, the maximum phytoplankton abundance was at $15 \mathrm{~m}$ and much of the biomass below $20 \mathrm{~m}$ was due to diatom species characteristic of the spring diatom bloom. Coccolithus pelagicus, Emiliania huxleyi, holococcolithophores and other small coccolithophores showed a similar and relatively low biomass at this station. At Area B, most of the phytoplankton biomass was concentrated in the upper mixed layer, as shown in Fig. 7C, D. At this area, coccolithophores were more abundant and formed a significant fraction of the total phytoplankton biomass $(>60 \%)$. E. huxleyi was the dominant species, with maximum abundance in the main thermocline $(15 \mathrm{~m})$. At Area $\mathrm{C}$, non-coccolithophore phytoplankton carbon biomass reached high values (Fig. 7E, F). Coccolithophores, mainly C. pelagicus, were dominant at and below the thermocline at this station. 


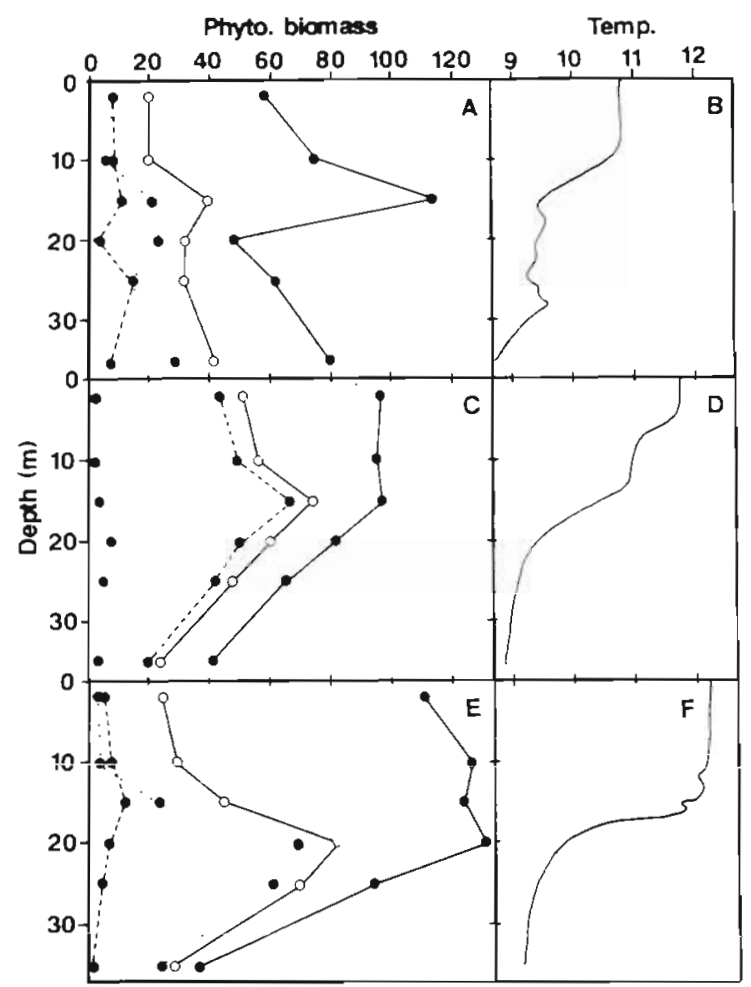

Fig. 7. Vertical distribution of phytoplankton $C$ biomass $(A$, $\left.C, E_{i} \mathrm{mg} \mathrm{m}^{-3}\right)$ and temperature $\left(B, D, E_{i}{ }^{\circ} \mathrm{C}\right)$ at Areas $A, B$ and $C$, represented by the in situ productivity stations: $60^{\circ} \mathrm{N}, 20^{\circ} \mathrm{W}$ (A, B); $61^{\circ} 06^{\prime} \mathrm{N}, 22^{\circ} 45^{\prime} \mathrm{W}(\mathrm{C}, \mathrm{D})$; and $61^{\circ} 12^{\prime} \mathrm{N}, 15^{\circ} 09^{\prime} \mathrm{W}$ $(E, F)$ respectively. Total phytoplankton $\mathrm{C}$ biomass $(\bullet-$ $\left.\mathrm{mg} \mathrm{m} \mathrm{m}^{-3}\right)_{\text {; }}$ total estimated coccolithophore $\mathrm{C}$ biomass $(0-0$, $\left.\mathrm{mg} \mathrm{m}^{-3}\right)$; Emiliania huxleyi biomass $\left(\bullet-.-\mathrm{mg} \mathrm{m}^{-3}\right)$; and Coccolithus pelagicus $\mathrm{C}$ biomass $\left(\bullet \ldots ., \mathrm{mg} \mathrm{m}^{-3}\right)$

The vertical distributions of chl $a$ and total particulate carbon were, in general, well correlated with total phytoplankton biomass (Figs. 7A, C, E \& 8A, C, E). However, a clear relationship between PIC and coccolithophores was not found, as a high proportion of the calcite was present in the water in the form of detached coccoliths or empty coccospheres. The contribution of PIC to TPC was higher at the western area (Area B). Photosynthetic rates in the mixed layer ranged between 40 and $80 \mathrm{mg} \mathrm{C} \mathrm{m}^{-3} \mathrm{~d}^{-1}$ (Fig. 8B, D, F). The vertical variability in photosynthesis observed at the 3 areas is attributable to the interaction between chl $a$ concentration and the pattern of light extinction with depth. Calcification was undetectable in the upper $15 \mathrm{~m}$ at Area A. However, low levels of inorganic carbon incorporation were observed below the thermocline (Fig 8B), mainly associated with an increase in the biomass of Coccolithus pelagicus (Fig. 7A). The highest calcification rates ( 6 to $8 \mathrm{mg} \mathrm{C}$ $\mathrm{m}^{-3} \mathrm{~d}^{-1}$ ) were recorded at the Emiliania huxleyidominated station (Area B) and in surface waters of the eastern station (Area C). Calcification never represented more than $20 \%$ of total carbon incorporation.

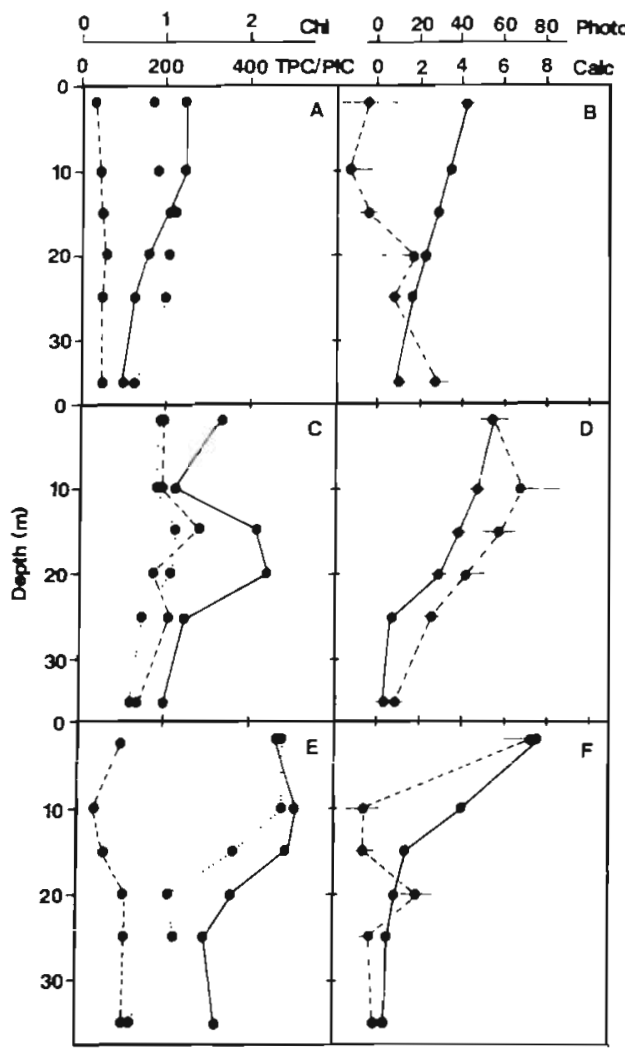

Fig. 8. Vertical distribution of phytoplankton standing stock variables $(A, C, E)$ and carbon incorporation rates $(B, D, F)$ at Areas $A, B$ and $C$, represented by the in situ productivity stations: $60^{\circ} \mathrm{N}, 20^{\circ} \mathrm{W}(\mathrm{A}, \mathrm{B}) ; 61^{\circ} 06^{\prime} \mathrm{N}, 22^{\circ} 45^{\prime} \mathrm{W}(\mathrm{C}, \mathrm{D})$; and $61^{\circ} 12^{\prime} \mathrm{N}, 15^{\circ} 09^{\prime} \mathrm{W}(\mathrm{E}, \mathrm{F})$ respectively. Left panels: total particulate carbon (TPC) $\left(\bullet, \mathrm{mg} \mathrm{m}^{-3}\right)$ and particulate inorganic carbon (PIC) $\left(\bullet-. \cdot \bullet \mathrm{mg} \mathrm{m}^{-3}\right)$; chl a $\left(\bullet \cdots \bullet \bullet \mathrm{mg} \mathrm{m}^{-3}\right)$.

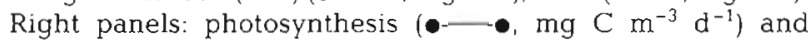
calcification $\left(\bullet-\cdots, \mathrm{mg} \mathrm{m}^{-3} \mathrm{~d}^{-1}\right)$ rates. Error bars: $\pm 1 \mathrm{SE}$

Integrated values of particulate stocks and carbon incorporation rates at the productivity stations illustrate the main geographic differences observed during the cruise (Table 1). Low biomass of Emiliania huxleyi and Coccolithus pelagicus, together with low PIC and calcification rates were measured at Area A. By contrast, in the E. huxleyi-dominated population in the western area (Area B), elevated PIC and calcification rates were found. In the eastern part (Area C), where C. pelagicus dominated, both calcification and photosynthesis rates were lower compared to the other stations; also relatively low chl a-normalized photosynthesis and a high ratio of detached coccoliths to E. huxleyi cells were observed.

\section{P-I and C-I relationships}

P-I experiments carried out using water samples taken from the surface along the cruise track indicated 
Table 1 Integrated carbon and chl a standing stocks and carbon incorporation rates over the upper $35 \mathrm{~m}$ of the water column at 5 productivity stations in June 1991

\begin{tabular}{|c|c|c|c|c|c|}
\hline Variable & $\begin{array}{c}60^{\circ} 00 \mathrm{~N} \\
20^{\circ} 00 \mathrm{~W} \\
19 \mathrm{Jun}\end{array}$ & $\begin{array}{c}61^{\circ} 06 \mathrm{~N} \\
22^{\circ} 41 \mathrm{~W} \\
23 \mathrm{Jun}\end{array}$ & $\begin{array}{c}61^{\circ} 06 \mathrm{~N} \\
22^{\circ} 43 \mathrm{~W} \\
24 \mathrm{Jun}\end{array}$ & $\begin{array}{c}61^{\circ} 12 \mathrm{~N} \\
15^{\circ} 09 \mathrm{~W} \\
28 \mathrm{Jun}\end{array}$ & $\begin{array}{c}61^{\circ} 12 \mathrm{~N} \\
15^{\circ} 09 \mathrm{~W} \\
29 \mathrm{Jun}\end{array}$ \\
\hline $\mathrm{POC}\left(\mathrm{mg} \mathrm{m}^{-2}\right)$ & 4795 & 3700 & 5826 & 9803 & 11023 \\
\hline $\mathrm{PIC}\left(\mathrm{mg} \mathrm{m}^{-2}\right)$ & 1706 & 6934 & 4637 & 2421 & 3318 \\
\hline $\mathrm{Chl}$ a $\left(\mathrm{mg} \mathrm{m}^{-2}\right)$ & 32.6 & 31.3 & 36.6 & 60.2 & 57.3 \\
\hline Phytoplankton biomass ( $\mathrm{mg} \mathrm{m}^{-2}$ ) & 2522 & 2785 & 2692 & 3845 & 3677 \\
\hline Coccolithophore biomass ( $\mathrm{mg} \mathrm{m}^{-2}$ ) & 1055 & 1825 & 1350 & 1275 & 1670 \\
\hline Emiliania huxleyi biomass $\left(\mathrm{mg} \mathrm{m}^{-2}\right.$ ) & 335 & 1577 & 1057 & 329 & 250 \\
\hline Coccolithus pelagicus biomass $\left(\mathrm{mg} \mathrm{m}^{-2}\right.$ ) & 549 & 137 & 58 & 589 & 1126 \\
\hline Coccoliths/E. huxleyj cells & 11.7 & 36.4 & 19.4 & 48.8 & 107.5 \\
\hline Photosynthesis (mg C m $\mathrm{m}^{-2} \mathrm{~d}^{-1}$ ) & 933 & 1054 & 1007 & 757 & 853 \\
\hline Photosynthesis/chl a [mg C (mg chl $\left.a)^{-1} \mathrm{~d}^{-1}\right]$ & 28.6 & 33.7 & 27.5 & 12.6 & 14.9 \\
\hline Calcification (mg C m ${ }^{-2} \mathrm{~d}^{-1}$ ) & 28.3 & 151.4 & 195.9 & 68.2 & 46.9 \\
\hline
\end{tabular}

the existence of a negative exponential relationship between the assimilation number $P_{\max }^{\mathrm{B}}$ and the concentration of PIC (Fig. 9A). $P_{\max }^{\mathrm{B}}$ values as low as $1 \mathrm{mg} \mathrm{C}$ (mg chl a $)^{-1} h^{-1}$ were estimated for phytoplankton populations from high PIC waters. A similar although less marked relationship was found between $\alpha_{\mathrm{B}}$ and PIC (Fig. 9B). Surface values of $P_{\max }^{\mathrm{B}}$ and $\alpha_{\mathrm{B}}$ were related according to the expression:

$$
\begin{gathered}
\alpha_{\mathrm{B}}=0.006( \pm 0.001) P_{\max }^{\mathrm{B}}-0.00004( \pm 0.00350), \\
\mathrm{r}^{2}=0.53, \mathrm{n}=20
\end{gathered}
$$

Only one sample (represented by a star in Fig. 9A, B) collected at the boundary zone between high and low reflectance waters (Area B) and composed of a mixed population of Emiliania huxleyi and small flagellates, did not fit this relationship. The phytoplankton in this sample was growing actively as revealed by the high assimilation number (Fig. 9A) and the relatively elevated calcification rates (Table 2 ). High values of $P_{\max }^{\mathrm{B}}$ [>3 $\mathrm{mg} \mathrm{C}(\mathrm{mg} \mathrm{chl} \mathrm{a})^{-1} \mathrm{~h}^{-1}$ ] were found south of $60^{\circ} \mathrm{N}$ and also in Icelandic shelf waters (Table 2).

Calcification was particularly significant in those C-I experiments carried out in the western area of the cruise track (Area B) (Table 2), although it was also measurable at one station of the eastern area, as previously shown in Fig. 8 . The highest $C_{\max }^{\mathrm{B}}$ rate recorded was $15.8 \mathrm{ng} C$ fixed $(\mu \mathrm{g} C \text { cocco })^{-1} \mathrm{~h}^{-1}$ at the position $61^{\circ} 07^{\prime} \mathrm{N}, 23^{\circ} 01^{\prime} \mathrm{W}$, where high values of $P_{\max }^{\mathrm{B}}$ and $\alpha_{\mathrm{B}}$ were observed (Table 2, Fig. 9A, B).

Comparison of the shapes of the P-I and C-I curves from 2 stations located at the western (Area B) and eastern regions (Area C) (Fig. 10), shows the complexity of such relationships for natural mixed populations of phytoplankton. As had been previously noted, Emiliania huxleyi dominated the coccolithophore population in Area B (Fig. 7C), whereas flagellates were the most abundant phytoplankton group in Area $C$, with $E$. huxleyi and Coccolithus pelagicus showing a similar but

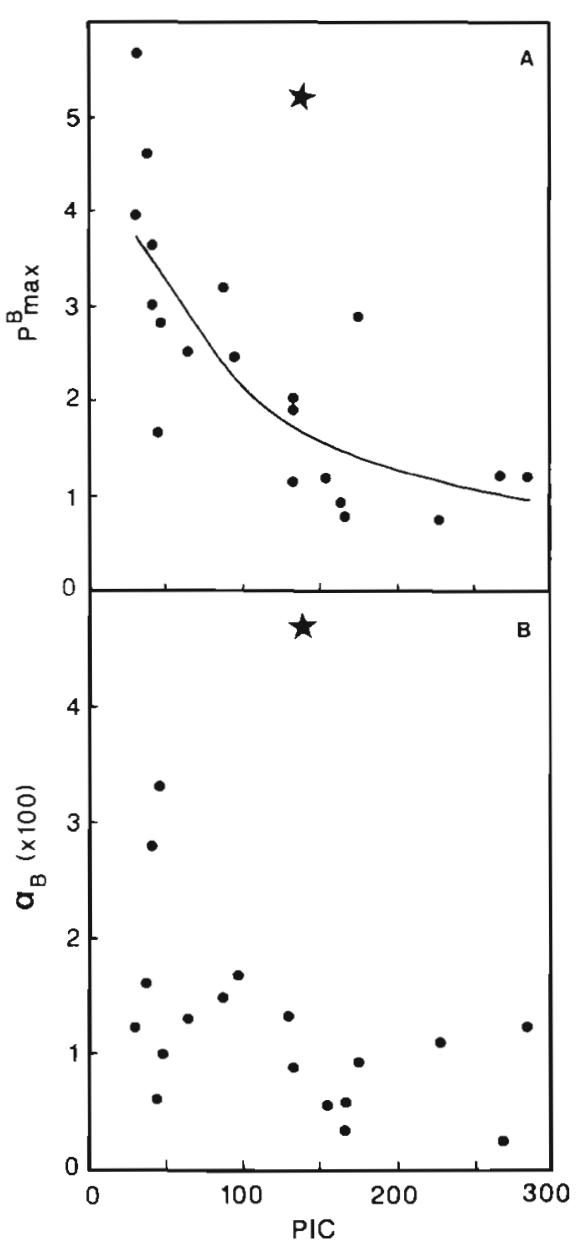

Fig. 9. Relationships between surface particulate inorganic carbon (PIC, $\mathrm{mg} \mathrm{m}^{-3}$ ) and (A) surface $P_{\max }^{\mathrm{B}}\left[\mathrm{mg} \mathrm{C}(\mathrm{mg} \mathrm{chl} \mathrm{a})^{-1}\right.$ $\mathrm{h}^{-1}$ ] and (B) surface $\alpha_{B}$ [mg C ( $\left.\mathrm{mg} \mathrm{chl} \mathrm{a}\right)^{-1} \mathrm{~h}^{-1}\left(\mu \mathrm{E} \mathrm{m} \mathrm{m}^{-2} \mathrm{~s}^{-1}\right)^{-1}$ ]. ( $\star$ ) sample taken on 25 June at $61^{\circ} 07^{\prime} \mathrm{N}, 23^{\circ} 01^{\prime} \mathrm{W}$ not included in analysis (see text). The $P_{\max }^{\mathrm{B}}$-PIC data set (A) was fitted to the exponential negative equation:

$$
\begin{gathered}
P_{\text {max }}^{\mathrm{B}}=3.95( \pm 0.89) \mathrm{e}^{-\{0012( \pm 0009) \mathrm{PIC})}+0.93( \pm 0.70) \\
( \pm \text { asymptotic SE })
\end{gathered}
$$


Table 2. Parameters of selected photosynthesis-irradiance (P-I) and calcification-irradiance (C-I) curves corresponding to surtace populations sampled along the cruise track. $P_{\max }^{\mathrm{B}}$ : maximum chlorophyll-normalized photosynthetic rate; $\alpha_{\text {photo }}$ initial slope of the P-I curve; $C_{\max }^{\mathrm{B}}$ : maximum biomass-normalized calcification rate $\left[\mu \mathrm{g} \mathrm{C}\right.$ incorporated $\left(\mu \mathrm{g} C \mathrm{cocco}^{-1} \mathrm{~h}^{-1}\right] ; \alpha_{\text {calcr: }}$ initial slope of the C-I curve. ND: not detectable

\begin{tabular}{|cccccc|}
\hline Latitude $(\mathrm{N})$ & Longitude $(\mathrm{W})$ & $P_{\max }^{\mathrm{B}}$ & $\alpha_{\text {photo }}$ & $C_{\max }^{\mathrm{B}}$ & $\alpha_{\text {calcif }}$ \\
\hline $55^{\circ} 50^{\prime}$ & $20^{\circ} 00^{\prime}$ & $6.59( \pm 0.14)$ & $0.0295( \pm 0.0012)$ & $\mathrm{ND}$ & $\mathrm{ND}$ \\
$58^{\circ} 22^{\prime}$ & $20^{\circ} 00^{\prime}$ & $3.66( \pm 0.10)$ & $0.0332( \pm 0.0023)$ & $\mathrm{ND}$ & $\mathrm{ND}$ \\
$60^{\circ} 00^{\prime}$ & $19^{\circ} 50^{\prime}$ & $2.82( \pm 0.07)$ & $0.0099( \pm 0.0004)$ & $\mathrm{ND}$ & $\mathrm{ND}$ \\
$61^{\circ} 07^{\prime}$ & $22^{\circ} 45^{\prime}$ & $2.50( \pm 0.09)$ & $0.0130( \pm 0.0009)$ & $0.0120( \pm 0.0040)$ & $0.000244( \pm 0.000056)$ \\
$61^{\circ} 07^{\prime}$ & $23^{\circ} 01^{\prime}$ & $5.21( \pm 0.14)$ & $0.0470( \pm 0.0032)$ & $0.0158( \pm 0.0019)$ & $0.000077( \pm 0.000023)$ \\
$60^{\circ} 53^{\prime}$ & $22^{\circ} 41^{\prime}$ & $1.94( \pm 0.13)$ & $0.0092( \pm 0.0018)$ & $0.0089( \pm 0.0009)$ & $0.000014( \pm 0.000002)$ \\
$61^{\circ} 31^{\prime}$ & $22^{\circ} 35^{\prime}$ & $1.18( \pm 0.38)$ & $0.0129( \pm 0.0026)$ & $\mathrm{ND}$ & $\mathrm{ND}$ \\
$63^{\circ} 35^{\prime}$ & $21^{\circ} 21^{\prime}$ & $3.94( \pm 0.18)$ & $0.0122( \pm 0.0009)$ & $\mathrm{ND}$ & $\mathrm{ND}$ \\
$61^{\circ} 09^{\prime}$ & $15^{\circ} 13^{\prime}$ & $2.45( \pm 0.06)$ & $0.0169( \pm 0.0014)$ & $\mathrm{ND}$ & $\mathrm{ND}$ \\
\hline
\end{tabular}

relatively low biomass in this region (Fig. $7 \mathrm{E}$ ). Chl anormalized photosynthetic rates were comparable at both stations. $P_{\max }^{B}$ values ranged from 2.2 to $3.1 \mathrm{mg} \mathrm{C}$ $(\mathrm{mg} \mathrm{chl} \mathrm{a})^{-1} \mathrm{~h}^{-1}$. Variations in $\mathrm{P} / \mathrm{chl} a$ with depth were slight. Photoinhibition of photosynthesis was only apparent at very high irradiances at the station located at Area $B$, where the temperature profile shows a secondary near-surface thermal structure (Fig. 7D).
At Area B, calcification in surface waters saturated at very low irradiance levels (Fig. 10A), whereas at Area $C$ no significant incorporation of inorganic carbon was detectable at the surface (Fig, 10C). Calcification saturated at higher irradiances than photosynthesis $\left(>600 \mu \mathrm{E} \mathrm{m} \mathrm{m}^{-2} \mathrm{~s}^{-1}\right)$ in subsurface waters in both areas (Fig. 10B, D). At Area $C$ subsurface calcification was found to be inhibited at elevated irradiances.
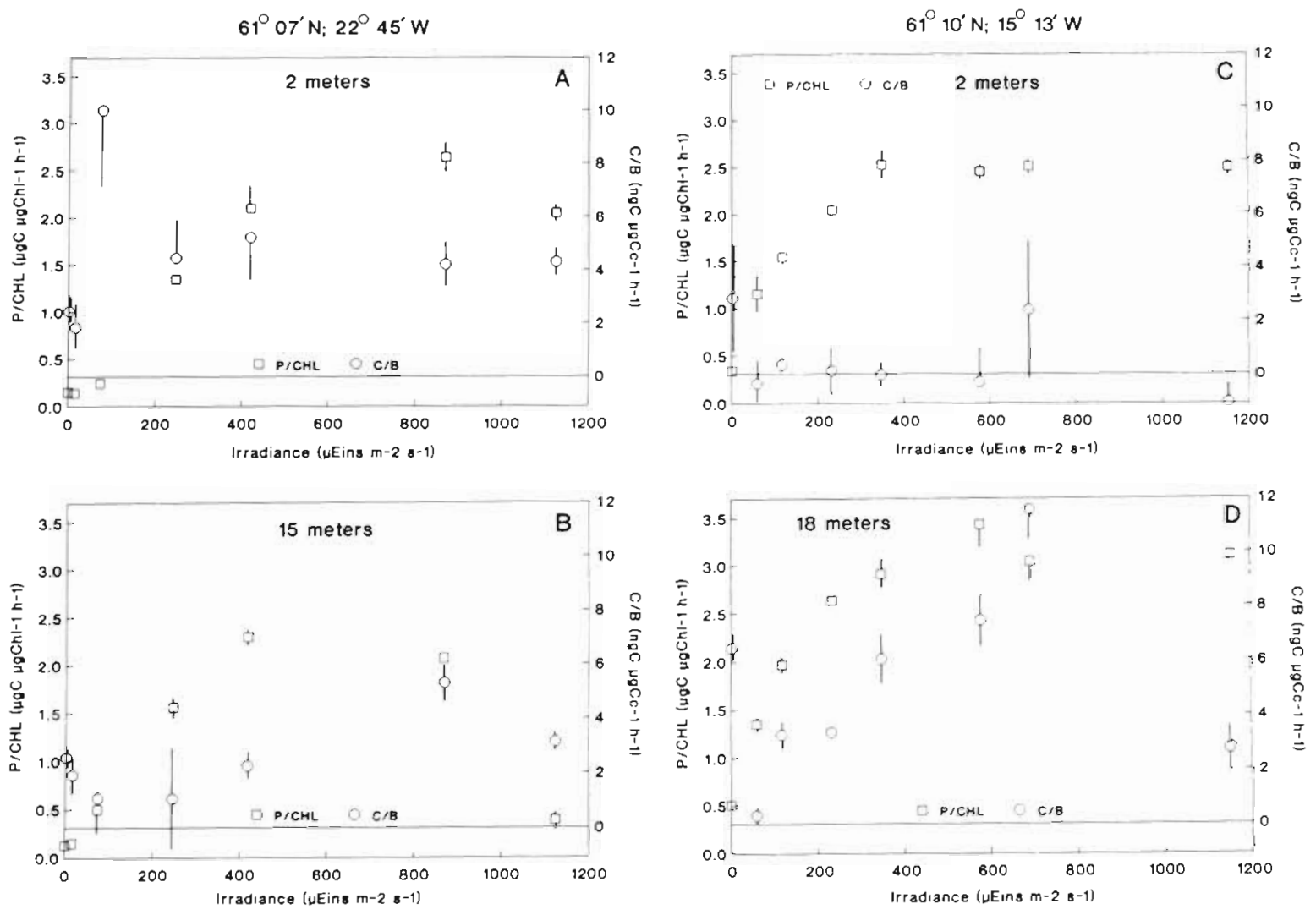

Fig 10. P-I and C-I relationships for surface $(2 \mathrm{~m})$ and subsurface $(15$ and $18 \mathrm{~m})$ populations at $61^{\circ} 07^{\prime} \mathrm{N}, 22^{\circ} 45^{\prime} \mathrm{W}(\mathrm{A}, \mathrm{B})$ and $61^{\circ} 10^{\prime} \mathrm{N}, 15^{\circ} 13^{\prime} \mathrm{W}$ (C. D). Photosynthesis rates were normalised to chlorophyll [P/CHL, mg C (mg chl a $\left.)^{-1} \mathrm{~h}^{-1}\right]_{\text {and }}$ calcification rates to Emiliania huxleyi + Coccolithus pelagicus biomass [C/B, ng $\mathrm{C}(\mu \mathrm{g} \mathrm{cocco}-\mathrm{C})^{-1} \mathrm{~h}^{-1}$ ] 


\section{Empirical model of surface calcification}

An empirical model of calcification was developed for surface coccolithophore populations by means of linear multiple step-wise regression techniques (Table 3). The original data set for the analysis consisted of 49 surface calcification experiments performed along 3 transects and parallel observations of the following variables: temperature, salinity, sigma-t, nitrate, beam attenuation, chl a, Emiliania huxleyi carbon biomass, Coccolithus pelagicus carbon biomass, holoccolithophore carbon biomass, total coccolithophore carbon biomass, photosynthetic rate and chl a-normalized photosynthesis. The first transect ran from $61^{\circ} 24^{\prime} \mathrm{N}, 22^{\circ} 57^{\prime} \mathrm{W}$ to $60^{\circ} 56^{\prime} \mathrm{N}, 22^{\circ} 55^{\prime} \mathrm{W}$ (10 samples). The other 2 transects were shown as in Figs. $5 \& 6$.

The model was statistically significant and explained $71.5 \%$ of the variability in surface calcification rates and, as a consequence, a good agreement between observed and predicted calcification rates was obtained (Fig. 11). Only 3 variables: Emiliania huxleyi biomass, Coccolithus pelagicus biomass and beam attenuation explained more than $1 \%$ of the variability in surface calcification rates. Calcification rates (CALC; $\mathrm{mg} \mathrm{C} \mathrm{m}^{-3} \mathrm{~h}^{-1}$ ) were related to $E$. huxleyi biomass (EHUX $\mathrm{mg} \mathrm{C} \mathrm{m}^{-3}$ ), C. pelagicus biomass ( $\mathrm{CPEL} ; \mathrm{mg} \mathrm{C} \mathrm{m}^{-3}$ ) and beam attenuation coefficient $\left(c ; \mathrm{m}^{-1}\right)$ according to the equation:

$$
\begin{aligned}
\text { CALC } & =0.029( \pm 0.004) \mathrm{EHUX}+0.016( \pm 0.006) \mathrm{CPEL} \\
& -0.371( \pm 0.104) c+0.17
\end{aligned}
$$

The highest percentage of variance was attributable to $E$. huxleyi biomass ( $52.2 \%$ ). The beam attenuation coefficient (c) was inversely related to calcification as shown by the negative coefficient in the regression equation, and explained $12.8 \%$ of the variability, whereas the biomass of $C$. pelagicus contributed $6.5 \%$ of the variance.

\section{DISCUSSION}

A comparison in terms of biomass and cell densities of Emiliania huxleyi between the 1991 bloom in the North Atlantic and others described in the literature

Table 3. Stepwise multiple regression analysis of calcification (dependent variable) and significant biological and environmental variables. Only those variables which explain more than $1 \%$ of the variance are shown. ( $\mathrm{n}=49$ )

\begin{tabular}{|lcccc|}
\hline Variable & $\mathrm{R}^{2}$ & \% variance & $F$ & $\mathrm{p}$ \\
\hline Emiliania huxleyi biomass & -5.522 & 52.17 & 41.45 & 0.0001 \\
Attenuation & 0.650 & 12.81 & 34.32 & 0.0001 \\
Coccolithus pelagicus biomass & 0.715 & 6.51 & 30.09 & 0.001 \\
\hline
\end{tabular}

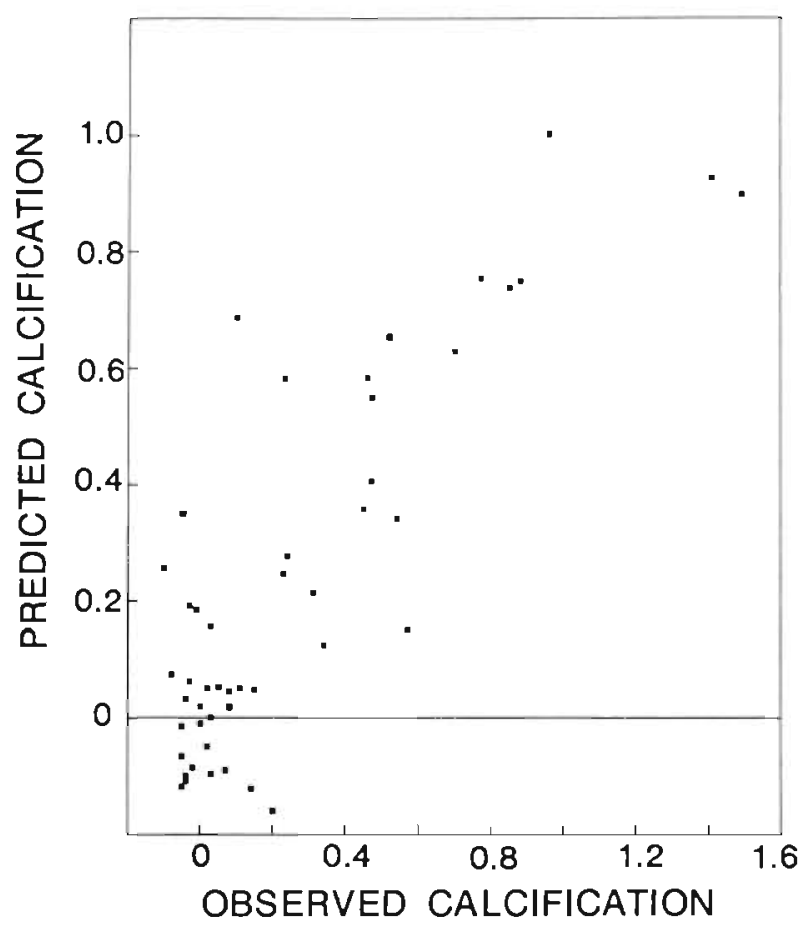

Fig. 11 Plot of observed against predicted calcification rates ( $\mathrm{mg} \mathrm{C} \mathrm{m} \mathrm{C}^{-3} \mathrm{~h}^{-1}$ ) as estimated from the multiple regression model shown in Table 3

reveals a number of similarities as well as some differences. Direct measurements of particulate calcium have shown similar maximum stocks of calcite-C of about 5 to $6 \mathrm{~g}$ calcite-C $\mathrm{m}^{-2}$ in coastal (C. García-Soto, R. D. Pingree, E. Fernández, D. S. Harbour unpubl.), shelf-edge (Holligan et al. 1983) and oceanic (Table 1) blooms. These results suggest that there is an upper threshold for coccolith production by E. huxleyi which is independent of the oceanographic region where the bloom develops and, therefore, also of the factors responsible of the decline of the bloom (see discussion below). Lower calcite- $C$ values (ca $1.5 \mathrm{~g} \mathrm{~m}^{-2}$ ) were reported for a coastal bloom in the Gulf of Maine (Balch et al. 1991, 1992) for which calcite-C was estimated from the number of coccoliths. However, based on PIC measurements (D. Townsend pers. comm.) the maximum calcite-C standing stock for a similar bloom in 1990 was also about $5 \mathrm{~g} \mathrm{~m}^{-2}$.

Open-ocean and coastal blooms of Emiliania huxleyi differ in terms of the coccolith to coccolithophore cells ratio. Values of 200 to 400 have been reported for on-shelf blooms (Balch et al. 1991, C. García-Soto, R. D. Pingree, E. Fernández, D. S. Harbour unpubl.), but values are much lower (ca 12) in a shelf-break bloom (Holligan et al. 1983), and also in this study, where it ranged between 20 and 40 
(Table 1). Maximum densities of detached coccoliths are usually close to $3 \times 10^{5}$ coccoliths $\mathrm{ml}^{-1}$ (Balch et al. 1991, Holligan et al. 1993, C. García-Soto, R. D. Pingree, E. Fernández, D. S. Harbour unpubl.) but typical cell densities were 2000 cells $\mathrm{ml}^{-1}$ in coastal waters as opposed to 8000 to 10000 cells $\mathrm{ml}^{-1}$ in shelf-break (Holligan et al. 1983) and oceanic blooms (Holligan et al. 1993). Marked differences in nitrate concentrations between coastal blooms, with values below $0.5 \mu \mathrm{M}$ (GREPMA 1988, Balch et al. 1991) and open ocean blooms, characterised by the presence of relatively elevated concentrations (up to $5 \mu \mathrm{mol} \mathrm{l}^{-1}$ ) of nitrate in the water (Holligan et al. 1983, Holligan et al. 1993; Figs, $5 \& 6$ ), may be a causal explanation for these discrepancies. In this regard, a number of laboratory experiments have shown that coccolith production per cell appears to be enhanced under nitrogen-depleted conditions (Baumann et al. 1978, Linschooten et al. 1991). It should be noted, however, that genotypic differences between coastal and oceanic E. huxleyi populations cannot be ruled out (Brand 1982, Young \& Westbroek 1991).

Little information is available on carbon assimilation within coccolithophore blooms (see Balch et al. 1992). In situ measured photosynthetic rates in an Emiliania huxleyi-dominated region at the southwestern edge of the 1991 bloom (Fig. 8) were about $40 \mathrm{mg} \mathrm{C} \mathrm{m}^{-3} \mathrm{~h}^{-1}$ in the upper mixed layer. Values reported in the Gulf of Maine close to the bloom centre were lower (ca $24 \mathrm{mg}$ $\mathrm{C} \mathrm{m}^{-3} \mathrm{~h}^{-1}$ ), probably due to nutrient limitation of photosynthesis in those populations, as indicated by the increase of carbon incorporated photosynthetically after additions of deep nutrient-rich water (Balch et al. 1992). Integrated daily rates of organic carbon production were about $1 \mathrm{~g} \mathrm{C} \mathrm{m}^{-2} \mathrm{~d}^{-1}$ at the western region of the North Atlantic bloom and at $60^{\circ} \mathrm{N}, 20^{\circ} \mathrm{W}$, and slightly lower at the $15^{\circ} \mathrm{W}$ section (Table 1 ). These rates are within the range measured for noncoccolithophore phytoplankton populations during an early summer study at $60^{\circ} \mathrm{N}, 20^{\circ} \mathrm{W}$ (Joint et al. 1993), and are slightly higher than predictions based on models of new production in the North Atlantic (Yentsch 1990). Photosynthetic rates in the coccolithophore bloom, however, were low compared with values measured during diatom blooms at $47^{\circ} \mathrm{N}, 20^{\circ} \mathrm{W}$ (ca $1.8 \mathrm{~g} \mathrm{C} \mathrm{m}^{-2} \mathrm{~d}^{-1}$ ) (Martin et al. 1993).

Significant rates of inorganic carbon production were measurable only in surface waters along the southern boundary of the bloom (Table 2) and also in some subsurface layers at stations north of $61^{\circ} \mathrm{N}$. In general, there was a direct relationship between high calcification and elevated values of $P_{\max }^{\mathrm{B}}$ or chl anormalized photosynthesis (Table 2, Figs. 5 \& 6), and therefore with actively growing phytoplankton populations. Calcification was undetectable within the high reflectance waters possibly due to the very low or negligible 'extra' energy available in populations characterised by extremely low $P_{\text {tnax }}^{\mathrm{B}}$ values (Table 2 , Fig, 9). Calcification rates, when measurable, were frequently higher in surface than in subsurface layers (Fig. 10D, F), as expected from the light dependence of calcification (Paasche 1966a, Sikes \& Wilbur 1982). At some stations, however, the maximum calcification rate was detected below the thermocline, associated with slight increases in coccolithophore biomass (Fig. 8B).

Typical in situ production rates of inorganic carbon at surface layers were 6 to $8 \mathrm{mg} \mathrm{C} \mathrm{m} \mathrm{m}^{-3} \mathrm{~h}^{-1}$ (Fig. 8). These values are lower than those reported by Balch et al. (1992) and too low to account for the accumulation rate of inorganic carbon within the bloom, as inferred from remote sensing observations (Holligan et al. 1993). The maximum calcification rate reported for Emiliania huxleyi cultures is $9.6 \mathrm{pg} \mathrm{C}$ cell ${ }^{-1} \mathrm{~d}^{-1}$ (Balch et al. 1992), compared to $2 \mathrm{pg} \mathrm{C}$ cell ${ }^{-1} \mathrm{~d}^{-1}$ in the region where E. huxleyi constituted almost $100 \%$ of the coccolithophore biomass (Area B). On the other hand, the maximum coccolithophore biomass-normalized calcification rate $\left(C_{\max }^{B}\right)$ measured in this study (Table 2) is equivalent to a production of $0.21 \mathrm{pg} C$ cell $^{-1} \mathrm{~h}^{-1}$. Taking a value of $0.47 \mathrm{pg} \mathrm{C}$ per coccolith (see 'Results'), the maximum coccolith production rate would be of 1 coccolith every 2 to $3 \mathrm{~h}$, comparable to that reported by Linschooten et al. (1991) for E. huxleyi cultures during the exponential phase of growth under low irradiance $\left(50 \mu \mathrm{E} \mathrm{m} \mathrm{m}^{-2} \mathrm{~s}^{-1}\right)$.

Laboratory experiments have shown that calcification saturates at lower light intensities than photosynthesis in Emiliania huxleyi (Paasche 1964, Blankley 1971, Balch et al. 1992). Although this physiological behaviour is of significance for the understanding of energy partitioning and vertical distribution of these organisms under natural conditions, it cannot be investigated at sea as the contribution of non-coccolithophore photosynthesis to total photosynthesis is unknown. Only more sophisticated approaches to those employed in this study, such as automatic sorting of $E$. huxleyi cells (e.g. by flow cytometry) and ${ }^{14} \mathrm{C}$ labelling of single cells, would enable the study of the relationship between photosynthesis and calcification during the development of natural blooms of E. huxleyi.

The results presented in this paper show that ${ }^{14} \mathrm{C}$ incorporation into calcite in darkness was always significant when calcification in the light was detectable (Fig. 10). The same pattern was also reported in culture work (Paasche 1966a, Balch et al. 1992). Depth profiles for the response of calcification to light, C-I curves, in an Emiliania huxleyi-rich area (Area B) displayed some remarkable features (Fig. 10), as calcification in subsurface populations saturated at higher irradiances 
than at surface. Three separate experiments were carried out at this station. In spite of the fact that independent sampling was conducted for each experiment, and that different incubation devices were employed, each gave the same shape of the calcificationirradiance curves as well as similar absolute rates of calcification. No direct explanation can be found for this physiological response, although they support the idea that the processes of calcification and photosynthesis are to a certain extent independent (Paasche 1965,1966 a).

The results presented here indicate that distinct developmental stages of the bloom were sampled during the cruise so that a feasible description of the sequence of events and processes can be advanced. An active population of Emiliania huxleyi, possibly characteristic of the early stages of the bloom, was growing at the southwestern boundary of the transect, as revealed by the elevated daily organic production (Table 1 ), $P_{\max }^{\mathrm{B}}$ values (Table 2) and calcification rates (Table 2, Fig. 10) and also by the relatively low ratio coccoliths to E. huxleyi cells in the water (Table 1). During this period of growth, the stoichiometry of photosynthesis and calcification for strongly calcifying clones of $E$. huxleyi is usually 1:1 (Paasche 1964, Balch et al. 1992, Nimer \& Merrett 1992), and the latter authors pointed out that at the very early phases, inorganic production might even exceed organic production. The situation observed at sea was different, as the maximum percentage of carbon incorporated into coccoliths was never higher than $25 \%$ due, in part, to the photosynthesis by non-coccolithophore phytoplankton. Coccoliths are formed continuously and at the same time they are shed into the water (Paasche 1968, Balch et al. 1992), thereby producing an increase in attenuation. At this stage, the detection of blooms of E. huxleyi become detectable by remote sensing.

In the northeastern area the low chl a-normalized organic production and daily calcification rates and the very high ratio of coccoliths to Emiliania huxleyi cells (Table 1), suggest that the phytoplankton community was at a late stage of development. The high carbon/chl a ratio (Fig. 4) is indicative of increased contribution of heterotrophic biomass. The slowing and eventually cessation of calcification during the stationary phase of growth has been reported in cultures of coccolithophores (Crenshaw 1964, Van der Wal et al. 1987). By contrast, coccolith detachment rate tends to increase during this phase (Balch et al. 1992). However, the highest calcification/photosynthesis ratios are usually detected during the transition period between the growth phases (Paasche 1969), reflecting differences in the energetic processes leading to the synthesis of organic and inorganic matter in coccolithophores (Paasche 1964, 1965). Our results also indi- cate that the presence of super-calcifying cells at the later stages of the bloom may be the result of ceased cell division rather than enhanced calcification rates.

Surface phytoplankton populations within the high reflectance waters in the core of the bloom were in a poor physiological state, as is clearly manifested by the extremely low $p_{\max }^{\mathrm{B}}$ values (Fig. 9A, Table 2) and negligible calcification rates (Table 2). The causes of the collapse of this Emiliania huxleyi bloom are still unknown, as inorganic nutrients concentrations and irradiance levels were sufficient for active growth even at the more reflective waters. Low metabolic rates within the high reflectance waters might be the result of depletion of some essential trace element needed for growth. However, coccolithophores have been found to be able to grow under extremely low concentrations of some of these elements (Brand et al. 1983, Brand, 1991).

Variability in surface calcification during the NE Atlantic 1991 bloom of Emiliania huxleyi could be accurately estimated from the biomass of E. huxley and Coccolithus pelagicus and the value of the beam attenuation coefficient (c) (Table 3, Fig. 11). The multiple regression model indicated that, as expected, calcification was not detectable $\left(-0.016 \mathrm{mg} \mathrm{C} \mathrm{m}^{-3} \mathrm{~h}^{-1}\right)$ in non-coccolithophore waters $\left(c=0.4 \mathrm{~m}^{-1}\right)$. Specific calcification rates can be estimated from the empirical model for the early stages of development of the bloom. For this calculation, it was assumed that cells of C. pelagicus were absent in the water, that a cellular concentration of 1000 cell $\mathrm{ml}^{-1}$ of E. huxleyi was characteristic of the early phase of the bloom, and that the amount of detached coccoliths in the water at that phase of growth was low and therefore, attenuation still remained at low levels (ca $0.5 \mathrm{~m}^{-1}$ ). The calcification rate estimated under such conditions was $0.36 \mathrm{pg}$ $\mathrm{C}$ cell ${ }^{-1} \mathrm{~h}^{-1}$. This value is within the range measured by Balch et al. (1992) (0.3 to 0.75) in cultures growing at $1160 \mu \mathrm{E} \mathrm{m}^{-2} \mathrm{~s}^{-1}$ in $\mathrm{F} / 50$ media, and considerably higher than the $0.2 \mathrm{pg} \mathrm{C}$ cell ${ }^{-1} \mathrm{~h}^{-1}$ reported by Nimer \& Merrett (1992) for populations maintained under low irradiance $\left(50 \mu \mathrm{E} \mathrm{m}^{-2} \mathrm{~s}^{-1}\right)$ in $\mathrm{F} / 2$ medium. The model also indicates that $E$. huxleyi-specific calcification rates are reduced by $40 \%$ for the range of beam attenuation values $\left(0.5\right.$ to $\left.3.5 \mathrm{~m}^{-1}\right)$ observed at sea (Holligan et al. 1993). These results suggest a decreasing trend in calcification rates from the exponential to the stationary phase of growth, which is coupled to a reduction in the maximum potential photosynthetic rate (Fig. 9A).

The maximum calcification rates estimated from the regression model were compatible with the stocks of particulate inorganic carbon measured within the bloom. Assuming an initial Emiliania huxleyi population density of 100 cells $\mathrm{ml}^{-1}, 16 \mathrm{~h}$ of light above the saturating level for calcification, and a growth rate of 
0.5 divisions $\mathrm{d}^{-1}$ at $12{ }^{\circ} \mathrm{C}$ (Paasche 1967), the highest PIC concentrations recorded in the bloom (ca $300 \mathrm{mg}$ $\mathrm{m}^{-3}$ ) would be reached in about $12.5 \mathrm{~d}$. This figure is consistent with the duration of the bloom as revealed by satellite imagery (Holligan et al. 1993).

The bloom of Emiliania huxleyi in the NE Atlantic produced about $1.0 \times 10^{6}$ t of calcite-C (Holligan et al. 1993). The immediate result of this synthesis was an alteration of the carbonate system in surface waters where the coccolithophores were present (Robertson et al. 1993). These authors concluded that the effect of calcification on alkalinity reduced the air-sea gradient of $\mathrm{CO}_{2}$ by about 10 to $40 \mu \mathrm{atm}$ compared to non-coccolithophore waters. It should be noted, however, that this coccolithophore bloom still represented a sink for carbon dioxide in the water column. Robertson et al. (1993) also estimated a 1:1 ratio organic:inorganic carbon uptake based on observations of potential alkalinity and total $\mathrm{CO}_{2}$. In this connection, our results revealed the existence of a significant relationship between the stock of particulate inorganic carbon $\left(\mathrm{mg} \mathrm{m}^{-3}\right.$ ) and particulate organic carbon estimated from total coccosphere counts, assuming the amount of carbon per living cell of $E$. huxleyi to be $0.13 \mathrm{pg} \mathrm{C}$. Both variables were related by the expression:

$$
\begin{gathered}
\mathrm{PIC}=1.32( \pm 0.07) \mathrm{POC}+48( \pm 27.0), \\
\mathrm{r}^{2}=0.86, \mathrm{n}=67
\end{gathered}
$$

The slope of this regression indicates that, in terms of carbon, inorganic production exceeded net photosynthesis (including cell mortality due to sinking and grazing) during this bloom. However, uncertainties derived from cell counting accuracy, cell to carbon conversion factors, and the possible sedimentation of empty coccospheres to subsurface layers suggest that the slope estimated here is consistent with the $1: 1$ photosynthesis to calcification ratio calculated from dissolved inorganic carbon parameters (Robertson et al. 1993). The significance of this coccolithophore bloom for air-sea exchanges of $\mathrm{CO}_{2}$ depends ultimately on the PIC to POC ratio for particulate material eventually buried into the sediments.

Acknowledgements. This work forms part of the community research project Biogeochemical Ocean Flux Study (BOFS). We are grateful to the officers and crew of the RSS 'Charles Darwin' and to the staff of the Research Vessels Services for their support of the work at sea, to Steve Groom for the processing of satellite information, to Kevin Kennington for help with chemical analysis and to Roy Lowry and Polly Machin at BODC, Proudman Oceanographic Laboratory, for data processing. E.F. acknowledges the receipt of a post-doctoral fellowship from FICYT (Principado de Asturias, Spain). The work of P.B. was supported by NERC Special topic grant No. GST/02/381. We are also grateful to Amersham International $\mathrm{Plc}$. for contributing the radio-isotopes used in this study. This is BOFS contribution No. 148 .

\section{LITERATURE CITED}

Aiken, J., Bellan, I. (1990). Optical oceanography: an assessment of a towed method. In: Herring, P. J., Campbell, A. K. Whitfield, M., Maddock, L. (eds.) Light and life in the sea. Cambridge University Press, Cambridge, p. 39-57

Balch, W. M., Holligan, P. M., Ackleson, S. G., Voss, K. J. (1991). Biological and optical properties of mesoscale coccolithophore blooms in the Gulf of Maine. Limnol. Oceanogr. 36: 629-643

Balch, W. M., Holligan, P. M., Kilpatrick, K. A. (1992). Calcification, photosynthesis and growth of the bloom-forming coccolithophore Emiliania huxleyi. Contin. Shelf Res. 12 : 1353-1374

Baumann, F. G., Isenberg, H. D., Gennaro, J. (1978). The inverse relationship between nutrient nitrogen concentration and coccolith calcification in cultures of the coccolithophorid Hymenomonas sp. J. Protozool. 25: 253-256

Berger, W. H., Keir, R. S. (1984). Glacial-Holocene changes in atmospheric $\mathrm{CO}_{2}$ and deep-sea record. Geophys. Monogr. Ser. 29: $337-351$

Blankley, W. F. (1971). Auxotrophic and heterotrophic growth and calcification in coccolithophorids. Ph.D. thesis, University of California, San Diego, p. 99-105

Bramlette, M. N. (1958). Significance of coccolithophorids in calcium carbonate deposition. Bull. Geol. Soc. Am. 69: $121-126$

Brand, L. E. (1982). Genetic variability and spatial patterns of genetic differentiation in reproductive rates of the marine coccolithophores Emiliania huxleyi and Gephyrocapsa oceanica. Limnol. Oceanogr. 27: 236-245

Brand, L. E. (1991). Minimum iron requirements of marine phytoplankton and the implications for the biogeochemical control of new production. Limnol. Oceanogr. 36: $1756-1771$

Brand, L. E., Sunda, W. G., Guillard, R. R. L. (1983). Limitation of marine phytoplankton reproductive rates by zinc, manganese, and iron. Limnol. Oceanogr. 28: 1182-1198

Brown, C., Yoder, J. (1993). Distribution pattern of coccolithophorid blooms in the Western North Atlantic. Contin. Shelf Res. (in press)

Crenshaw, M. A. (1964). Coccolith formation by two marine coccolithophorids, Coccolithus huxleyi and Hymenomonas sp. Ph.D. thesis, Duke University, Durham, p. 48-50

De Jong, E. W., Van der Val, P., Borman, A. H., De Vrind J. P. M., Van Emburg, P., Westbroek, P., Bosch, L. (1983) Calcification in coccolithophorids. In: Westbroek, P. de Jong, E. W. (eds.) Biomineralization and biological metal accumulation. D. Reidel Publishing Company, Dordrecht, p. 291-301

Gran, H. H. (1912). Pelagic plant life. In: Murray, J., Hjort, J. (eds.) The depths of the ocean. MacMillan and $\mathrm{Co}$. London, p. 307-386

GREPMA (Groupe de Recherches Pelágiques en Manche et Atlantique) (1988). Satellite (AVHRR/NOAA-9) and ship studies of a coccolithophorid bloom in the western English Channel. Mar. Nature 1. 1-14

Groom, S. B, Holligan, P. M. (1987). Remote sensing of coccolithophore blooms. Adv. Space Res. 7: 73-78

Holligan, P. M. Aarup, T., Groom, S. B. (1989). The North Sea: satellite colour atlas. Contin. Shelf Res. 9: 665-766

Holligan, P. M., Fernández, E., Aiken, J., Balch, W. M., Boyd, P., Burkill, P. H., Finch, M., Groom, S. B., Malin, G., Muller, K., Purdie, D. A., Robinson, C., Trees, C., Turner, S. M., van der Wal, P. A. (1993). A biogeochemical study of the coccolithophore Emiliania huxleyi in the North Atlantic. Global Biogeochem. Cycles (in press) 
Holligan, P. M., Harris, R. P., Newell, R. C., Harbour, D. S. Head, R. N., Linley, E. A. S., Lucas, M. I., Tranter, P. R. G., Weekley, C. M. (1984). Vertical distribution and partition ing of organic carbon in mixed, frontal and stratified waters of the English Channel. Mar. Ecol. Prog. Ser. 14: $111-127$

Holligan, P. M., Viollier, M., Harbour, D. S., Camus, P., Champagne-Philippe, M. (1983). Satellite and ship studies of coccolithophore production along a continental shelfedge. Nature 304: 339-342

Jassby, A. D., Platt, T. (1976). Mathematical formulation of the relationship between photosynthesis and light for phytoplankton. Limnol. Oceanogr. 21: 540-547

Joint, L. R., Pomroy, A. J. (1983). Production of picoplankton and small nanoplankton in the Celtic Sea. Mar. Biol. 77: $19-27$

Joint, I. R., Pomroy, A. J. (1986). Photosynthetic characteristics of nanoplankton and picoplankton from the surface mixed layer. Mar. Biol. 92: 465-474

Joint, I. R., Pomroy, A. J., Savidge, G., Boyd, P. (1993). Sizefractionated primary productivity in the northeast Atlantic in May-July 1989. Deep Sea Res. 40: 423-440

Klaveness, D., Paasche, E. (1979). Physiology of coccolithophorids. In: Levandowski, M., Hutner, S. H. (eds.) Biochemistry and physiology of Protozoa, Vol. 1. Academic Press, London, p. 191-213

Linschooten, C., Van Bleijswijk, J. D. L., Van Emburg, P. R., De Vrind, J. P. M., Kempers, E. S., Westbroek, P., De Vrind-De Jong, E. W. (1991). Role of the light-dark cycle and medium composition on the production of coccoliths by Emiliania huxleyi (Haptophyceae). J. Phycol. 27:82-86

Martin, J. H., Fitzwater, S. E., Gordon, R. M., Hunter, C. N. Tanner, S. J. (1993). Iron, primary production and carbonnitrogen flux studies during JGOFS North Atlantic Bloom Experiment. Deep Sea Res. 40: 115-134

Nimer, N. A., Merrett, N. J. (1992). Calcification and utilization of inorganic carbon by the coccolithophorid Emiliania huxleyi Lohman. New Phytol. 121: 173-177

Okada, H., McIntyre, A. (1977). Modern coccolithophores of the Pacific and North Atlantic Oceans. Micropaleontology 23: $1-55$

Paasche, E. (1963). The adaptation of the carbon-14 method for the measurement of coccolith production in CoccoLithus huxleyi. Physiol. Plant. 16: 186-200

Paasche, E. (1964). A tracer study of the inorganic carbon uptake during coccolith formation and photosynthesis in the coccolithophorid Coccolithus huxleyi. Physiol. Plant. Suppl. III. 1-82

Paasche, E. (1965). The effect of 3-(p-chlorophenyl)1,1-dimethylurea (CMU) on photosynthesis and lightdependent coccolith formation in Coccolithus huxleyi. Physiol. Plant. 18: 138-145

Paasche, E. (1966a). Adjustment to light and dark rates of coccolith formation. Physiol. Plant. 19: 271-278

Paasche, E. (1966b). Action spectrum of coccolith formation. Physiol. Plant. 19: 770-779

Paasche, E. (1967). Marine plankton algae grown with lightdark cycles. I. Coccolithus huxleyi. Physiol. Plant. 20: 946-956

This article was submitted to the editor
Paasche, E. (1968). The effect of temperature, light intensity and photoperiod on coccolith formation. Limnol. Oceanogr. 13: 178-181

Paasche, E. (1969). Light-dependent coccolith formation in the two forms of Coccolithus pelagicus. Arch. Mikrobiol. 67: $199-208$

Platt, T., Gallegos, C. L., Harrison, W. G. (1980). Photoinhibition of photosynthesis in natural assemblages of marine phytoplankton: J. mar. Res. 38: 687-701

Robertson, J. E., Robinson, C., Turner, D. R., Holligan, P. M. Watson, A. J., Boyd, P., Fernandez, E., Finch, M. (1993) The impact of a coccolithophore bloom on oceanic carbon uptake in the N.E. Atlantic Ocean during summer 1991 Deep Sea Res. (in press)

SAS Institute (1985). SAS user's guide: statistics, Version 5 edn. SAS Institute Inc., Cary, NC

Sikes, C. S., Fabry, V. J. (1993). Photosynthesis, $\mathrm{CaCO}_{3}$ deposition, coccolithophorids and the global carbon cycle. In Tolbert, N. E., Preiss, J. (eds.) Photosynthetic carbon metabolism and regulation of atmospheric $\mathrm{CO}_{2}$ and $\mathrm{O}_{2}$. (in press)

Sikes, C. S., Roer, R. D., Wilbur, K. M. (1980). Photosynthesis and coccolith formation: inorganic carbon sources and net inorganic reaction deposition. Limnol. Oceanogr. 25: $248-261$

Sikes, C. S., Wilbur, K. M. (1982). Functions of coccolith formation. Limnol. Oceanogr. 27: 18-26

Trees, C. C., Aiken, J., Hirche, H.-J., Groom, S. B. (1992). Biooptical variability across the Arctic front. Polar Biol. 12: $454-461$

Van der Wal, P., De Jong, J., Westbroek, P., De Bruijn, W. C. (1983). Calcification in the coccolithophorid alga Hymenomonas carterae. Ecol. Bull. 35: 251-258

Van der Wal, P., de Vrind, J. P. M., de Vrind-de Jong, E. W. Borman, A. H. (1987). Incompleteness of the coccosphere as a possible stimulus for coccolith formation in Pleurochrysis carterae (Prymnesiophyceae). J. Phycol. 23: $218-221$

Volk, T. (1989). Sensitivity of climate and atmospheric $\mathrm{CO}_{2}$ to deep-ocean and shallow-ocean carbonate burial. Nature 337: $637-638$

Watabe, N., Wilbur, K. M. (1966). Effect of temperature on growth, calcification and coccolith form in $\mathrm{CocCO}$ lithus huxleyi (Coccolithineae). Limnol. Oceanogr. 11 $567-575$

Westbroek, P., de Vrind-de Jong, E. W., Van der Wal, P., Borman, A. H., de Vrind, J. P. M. (1985). Biopolymermediated calcium and manganese accumulation and biomineralization. Geol. Mijnbow 64:5-15

Whitfield, M., Watson, A. J. (1983). The influence of biomineralization on the composition of seawater. In: Westbroek, P., de Jong, E. W. (eds.) Biomineralization and biological metal accumulation. D. Reidel Publishing Company, Dordrecht, p. 57-72

Yentsch, C. S. (1990). Estimates of 'new production' in the mid-North Atlantic. J. Plankton Res. 12: 717-734

Young, J. R., Westbroek, P. (1991). Genotypic variation in the coccolithophorid species Emiliania huxleyi. Mar. Micropal. 18: 5-23

Manuscript first received: February 18, 1993

Revised version accepted: May 11, 1993 